\title{
ENding Patent LaW's Willfulness Game
}

\author{
By Mark A. Lemley ${ }^{\dagger}$ and Ragesh K. Tangri ${ }^{\ddagger}$
}

\begin{abstract}
Patent law's doctrine of willful infringement turns the attorney-client privilege on its head by requiring companies confronted with a patent first to obtain a written opinion of counsel and then to disclose that opinion in court. The willful infringement game is a costly one with perverse consequences for patent law. The complex rules of the game cause attorneys to withhold information and candid advice from their clients because they know the advice may later have to be disclosed to the other side. The current rules also infect pre-litigation advice, essentially making it impossible for a competent lawyer to advise a client that a competitor's patent should be avoided. Perhaps worst of all, they discourage engineers and companies from reading patents in the first place, thereby undermining the disclosure function that is at the foundation of the patent system.

This Article proposes that the best approach to reducing these perverse effects is first to redefine willful infringement as adopting a technology with knowledge that it was derived from the patentee, and second to adjust the premium charged for it. Changing the focus of the inquiry to the time of adoption would reduce the number of accused infringers that would be required to seek an opinion of counsel and minimize the scope of the disclosure for the rest. Adjusting the damages premium by limiting willful infringement damages awards to attorneys fees in the bulk of cases will ensure that the willfulness doctrine fulfills its purpose of compensating the patentee while not over-deterring competitors in the marketplace. Narrowing the willfulness doctrine and limiting the amount of damages awarded are consistent with the purposes of patent law and will put an end to a longstanding and dangerous game.
\end{abstract}

(C) 2003 Mark A. Lemley and Ragesh K. Tangri

$\dagger$ Elizabeth Josslyn Boalt Chair in Law, University of California at Berkeley (Boalt Hall); of counsel, Keker \& Van Nest LLP.

$\ddagger$ Partner, Keker \& Van Nest LLP. The views expressed in this Article are our own, not those of our clients or colleagues.

We thank Chris Cotropia, Daralyn Durie, Rose Hagan, Scott Kieff, Doug Lichtman, Chris Martiniak, Joe Miller, Lee Van Pelt, Elizabeth Rader, and participants in the Advanced Patent Law Institutes at the Berkeley Center for Law and Technology and the University of Texas School of Law for their helpful suggestions. 


\section{TABle of Contents}

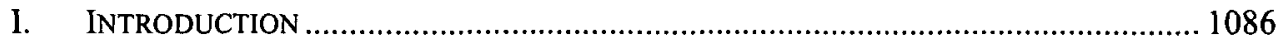

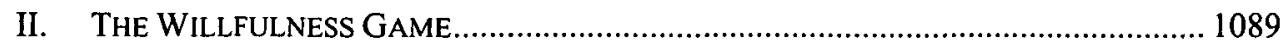

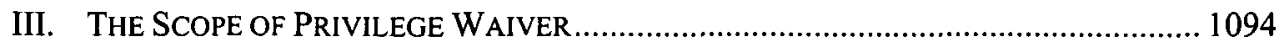

A. The Waiver Can Vary by Time .......................................................... 1094

B. The Waiver Can Vary by Subject Matter .................................................. 1096

1. Attorney-Client Versus Work Product Privilege ................................. 1096

2. Opinion Counsel Versus Trial Counsel ................................................ 1098

C. Implications of the Various Rules ........................................................... 1099

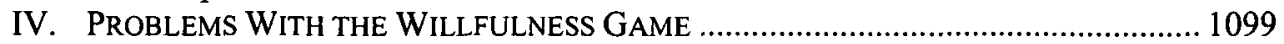

A. Undermining Patent Disclosures .......................................................... 1100

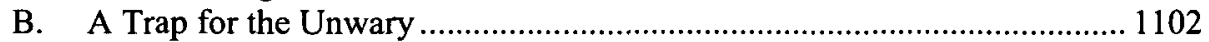

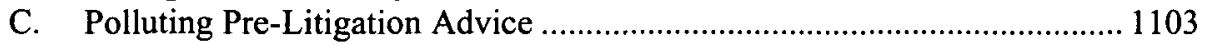

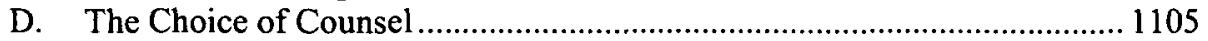

E. Polluting Litigation Advice and Settlements........................................... 1106

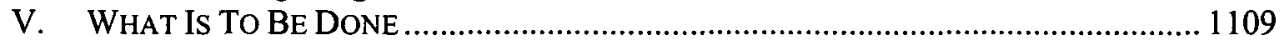

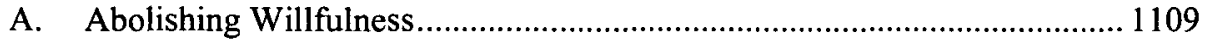

B. Eliminating the Requirement to Waive Privilege ..................................... 1113

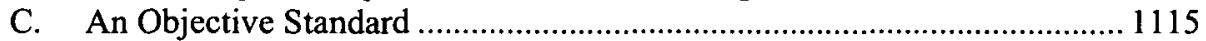

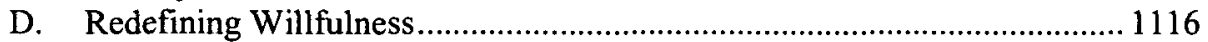

E. Adjusting the Willfulness Premium ........................................................ 1122

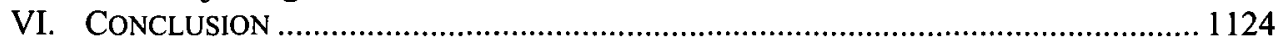

\section{INTRODUCTION}

The attorney-client privilege lies at the heart of the legal system. Attorneys can give honest advice to their clients because they know that this advice will remain confidential. Attorneys cannot breach the privilege, even in extreme circumstances. They have an ethical obligation to maintain client confidences. ${ }^{1}$ Clients, in turn, can feel comfortable telling their lawyers the truth because they know that this information will remain confidential. Without the attorney-client privilege, the adversary system would be unrecognizable. ${ }^{2}$

1. The Model Rules of Professional Responsibility impose upon lawyers a duty of confidentiality that can be breached only in a few extreme cases. MODEL CODE OF PROF'L RESPONSIBILITY DR 4-101 (1981); MODEL RULES OF PROF'L CONDUCT R. 1.6 (Discussion Draft 2002).

2. See Upjohn Co. v. United States, 449 U.S. 383, 389 (1981) (discussing the values served by the attorney-client privilege); Quantum Corp. v. Tandon Corp., 940 F.2d 642, 644 (Fed. Cir. 1991) (calling the attorney-client privilege a "basic, time-honored privilege [warranting] careful consideration"). On the role of attorney-client privilege, see generally CHARLES W. WOLFRAM, MODERN LEGAL ETHICS 250-96 (1986). Cf. Stephen McG. Bundy \& Einer Richard Elhauge, Do Lawyers Improve the Adversary System? A General Theory of Litigation Advice and its Regulation, 79 CALIF. L. REV. 313 (1991) (discussing the ways in which the attorney-client privilege distorts the litigation process). 
Patent law turns the attorney-client privilege on its head. Patent law punishes willful infringers by subjecting them to treble damages. ${ }^{3}$ An odd set of legal rules stemming from patent law's effort to determine what constitutes willful infringement effectively requires companies confronted with a patent first to obtain a written opinion of counsel and then to disclose that opinion in court. To do that, the accused infringer will have to waive its attorney-client privilege in virtually every case. Even worse, the law puts the question whether an accused infringer will have to waive privilege in the hands of the patent owner, who can send a carefully crafted letter putting a potential defendant on notice of the patent. A patent owner thus triggers the obligation to obtain a written opinion of counsel without actually threatening to sue anyone. In turn, accused infringers who are aware of these rules respond to such letters by obtaining a sort of pseudo-legal advice that both they and their attorneys recognize to be a construct. Both plaintiffs and defendants are playing a costly game. Part II explains the legal rules leading to the game.

If the game progresses to the litigation stage and the defendant proffers the opinion it obtained as a defense to alleged willful infringement, the court must confront questions of privilege waiver. All courts to have considered the issue have required defendants accused of willful infringement to waive privilege to some degree. Courts have split widely on the breadth of that waiver, however. Some have created a limited waiver, focusing on the advice the accused infringer received at the time it began the allegedly infringing activity. Others have required a broader waiver of privilege, extending to all subject matter discussed in the attorney's opinion. Still other courts have held that the waiver extends to litigation counsel, who presumably must turn over their communications relating to trial preparation and strategy. Finally, a significant number of courts have held that the waiver of privilege extends not only to attorney-client communications, but also to attorney work product, even if not communicated to the client. Part III explores these cases in detail.

Part IV explains the perverse consequences of the broad waiver of privilege in patent law. Some of these consequences affect litigationlawyers and clients who know that the lawyer's advice will be disclosed to the other side will behave differently, withholding information and candid advice from each other. But other consequences extend beyond litigation. They infect pre-litigation advice, essentially making it impossible for a

3. 35 U.S.C. $\S 284$ (2000). The statute does not specifically refer to trebling for willfulness, but courts have found willfulness sufficient to qualify for treble damages. See, e.g., Jurgens v. CBK, Ltd., 80 F.3d 1566, 1570 (Fed. Cir. 1996). 
competent lawyer to advise a client that a competitor's patent should be avoided. The rules of the willful infringement game set traps for the unwary, who may not realize the consequences of failing to obtain the necessary written opinion of counsel. They interfere with a client's ability to choose counsel. And they discourage engineers and companies from reading a competitor's patents at all, thereby undermining the disclosure function that is at the foundation of the patent system.

Part V offers solutions. One possibility is to abolish the willfulness rule entirely. We ultimately reject this approach because we worry that ordinary patent damages alone would be insufficient to deter infringement optimally in many cases. Another possibility is to abolish the rule that requires disclosure of opinions of counsel. While a good idea, this option would not solve the problems created by the willfulness game, because many defendants will still need to rely on the opinion of counsel in order to disprove willfulness.

Instead, we think the better approach to willful infringement is first to redefine it as adopting a technology with knowledge that it was derived from the patentee, and second to adjust the premium charged for it. Many of the problems with the willfulness rules stem from the fact that willfulness is an ongoing inquiry. The ongoing nature of the inquiry adversely affects a defendant that develops or adopts a technology in good faith but later learns it is infringing a patent. Changing the focus of the inquiry to the time of adoption is consistent with the ordinary understanding of willfulness outside of patent law and would help end the willfulness game. An independent developer could never be a willful infringer, and thus would neither need to obtain nor disclose in court a written opinion of counsel merely because it later learned of a patent. By contrast, an accused infringer would need advice of counsel if it was aware of a patent and affirmatively sought to design around that patent. Such an accused infringer therefore would have to waive privilege. But since only the accused infringer's intent at the time of adoption would matter, the scope of privilege waiver would be limited to communications at the time of adoption and would not infect the advice given by litigation counsel.

Finally, Part V also analyzes the economics underlying the amount of the damage premium imposed based on a finding of willfulness. As a result of that analysis, we suggest changing that premium by limiting it to awarding attorneys fees to successful plaintiffs. 


\section{THE WILLFULNESS GAME}

Increased punishment for willful violations is common to most intellectual property regimes. Unlike copyright and trade secret law, patent law punishes not only those who copy from the intellectual property owner but also those who develop the same invention independently. ${ }^{4}$ However, like other forms of intellectual property, patent law treats those who intentionally infringe a right more harshly than those who act innocently. ${ }^{5}$ In patent law, this harsher treatment takes the form of judicial discretion to enhance damages and award attorney fees if the court determines a defendant's infringement to be willful. ${ }^{6}$

Identifying willful infringers naturally requires the law to define willfulness. Patent law follows the rest of intellectual property ${ }^{7}$ by defining willful conduct to require awareness that the act was illegal. ${ }^{8}$ Requiring

4. See, e.g., Robert P. Merges et al., Intellectual Property IN the New TECHNOLOGICAL AgE 24 (3d ed. 2003).

5. Copyright law enhances statutory damages for willful infringement. 17 U.S.C. $\S 504(c)(2)(2000)$. Trade secret and trademark law permit trebling of damages for willful misappropriation. See, e.g., 15 U.S.C. $\$ 1117$ (2000) (specifying damages for willful trademark infringement); UNIF. TRADE SECRET ACT $\S 3$ (c) (2000) (specifying damages for willful trade secret infringement). Copyright, trademark, and trade secret law, unlike patent law, also include criminal penalties for willful infringement. See 17 U.S.C. $\S 506$ (setting forth federal criminal copyright infringement penalties); 15 U.S.C. $\S \S 1114$, $1116-18,1120,1122,1125$ (setting forth federal trademark infringement penalties); 18 U.S.C. $\$ \S 1831-39$ (2000) (setting forth federal criminal trade secret infringement penalties); Cal. Penal Code $\S 499 c$ (West 1999) (setting forth California criminal trade secret infringement penalties).

6. 35 U.S.C. $\$ 284$ (permitting enhancement of damages for willful patent infringement); id. $\S 285$ (permitting attorney fees for willful patent infringement). Courts have emphasized that an award of enhanced damages and attorney fees is discretionary, not mandatory, when willful infringement is found. Cybor Corp. v. FAS Techs., 138 F.3d 1448, 1461 (Fed. Cir. 1998) (en banc). Indeed, one recent study found that only about a third of willfulness cases involved enhanced damages, and that that number was declining over time. Jennifer L. Knabb \& Michael J. Jeffords, Trends in Patent Infringement Damages, 21 IPL NEWSL. 22, 24 (2003).

7. See Dane S. Ciolino \& Erin A. Donelan, Questioning Strict Liability in Copyright, 54 Rutgers L. REv. 351, 406-07 (2002); R. Anthony Reese, Historical Development of Mental State Considerations in Copyright Infringement (Nov. 24, 2003) (unpublished manuscript, on file with author) (observing that copyright law historically defined willfulness to require not only intent to act but awareness that the act was illegal).

8. Contributory infringement, like willful infringement, imposes a knowledge requirement. See, e.g., Aro Mfg. Co. v. Convertible Top Replacement Co., 377 U.S. 476, 488 (1964) (requiring a showing that the infringer knew the product it made "was both patented and infringing" to satisfy the knowledge requirement in the context of contributory infringement); see also Ryco, Inc. v. Ag-Bag Corp., 857 F.2d 1418, 1428 (Fed. Cir. 1988) (defining the test for willfulness in the context of patent law as whether a defen- 
awareness of illegality departs from the willfulness rule in other kinds of tort cases ${ }^{9}$ in which intentional action can be willful even if the actor did not know that it was illegal. A defendant must be aware the patent exists and understand that the patent is both valid and infringed in order to be a willful infringer.

Defendants may become aware of a patent in several ways. First, an accused infringer may discover a patent on its own. A corporation can find a relevant patent during a patentability search for a new invention; or if one of its engineers regularly reads new patents in her field, observes a patent number marked on a competitor's product, ${ }^{10}$ or even peruses a news article. Second, a company may learn of a patent by having the Patent and Trademark Office cite it as prior art while the company is prosecuting its own patent application. Finally, a patent owner can put a competitor on notice of the existence of a patent by sending the competitor a letter identifying the patent and giving some indication of how it relates to the competitor's business. ${ }^{11}$

Notice of the existence of a patent does not in itself suffice to establish willfulness, however. To be willful, an accused infringer must understand

dant could have "any confidence that a court might hold the patent invalid or not infringed”). But see Sandisk Corp. v. Lexar Media, Inc., 91 F. Supp. 2d 1327, 1335 (N.D. Cal. 2000) (suggesting, incorrectly in our view, that knowledge of the patent and of the infringing activity will suffice for contributory infringement liability).

9. The law outside of intellectual property generally treats conduct as intentional if it was done deliberately, even if the actor is not aware that the conduct is wrongful. It is a fundamental maxim of criminal law, for example, that a mistake of law does not excuse. See Stuart P. Green, Plagiarism, Norms, and the Limits of Theft Law: Some Observations on the Use of Criminal Sanctions in Enforcing Intellectual Property Rights, 54 HaSTINGS L.J. 167, 185 n.67 (2002); Douglas Husak \& Andrew von Hirsch, Culpability and Mistake of Law, in ACTION AND VALUE IN CRIMINAL LAW 157-74 (Stephen Shute et al. eds., 1993); Dan M. Kahan, Ignorance of the Law Is an Excuse-But Only for the Virtuous, 96 MiCH. L. REV. 128, 135 (1997).

10. On the role of marking in patent law, see Roger D. Blair \& Thomas F. Cotter, Strict Liability and Its Alternatives in Patent Law, 17 BERKELEY TECH. L.J. 799 (2002).

11. These letters are normally quite circumspect, because a letter that actually comes out and says that the competitor is infringing the patent will give the recipient a reasonable apprehension that they will be sued, and therefore permit the recipient to sue for declaratory judgment first. See, e.g., Scholle Corp. v. Blackhawk Molding Co., 133 F.3d 1469,1472 (Fed. Cir. 1998) (discussing what content in a threat letter will justify a declaratory judgment action). An accused infringer who sues first gets to choose a more favorable forum and go first in court. Empirical evidence has suggested that declaratory judgment patent plaintiffs are $14 \%$ more likely to win than similarly situated patent defendants. Kimberly A. Moore, Forum Shopping in Patent Cases: Does Geographic Choice Affect Innovation?, 79 N.C. L. REV. 889, 920-21 (2001). 
that the patent is valid and that what it is doing infringes the patent. ${ }^{12} \mathrm{De}$ termining what a corporation thinks, particularly about questions as difficult and abstruse as patent validity and infringement, is a thorny evidentiary problem. In patent law, the Federal Circuit has effectively hinged the question of intent on whether the accused infringer obtained and believed a competent opinion of counsel. Failure to obtain such an opinion creates a presumption of willfulness, ${ }^{13}$ and failure to disclose an opinion in court after it was obtained creates a presumption that the opinion was unfavorable. ${ }^{14}$ While both presumptions are rebuttable, in practice they are likely

12. See, e.g., Ryco, 857 F.2d at 1428.

13. Underwater Devices, Inc. v. Morrison-Knudsen Co., 717 F.2d 1380, 1389-90 (Fed. Cir. 1983) (creating a duty to obtain an opinion of counsel when confronted with a patent). While the Federal Circuit decision in Read Corp. v. Portec, Inc., 970 F.2d 816 (Fed. Cir. 1992), observed that "the absence of such advice [of counsel] does not mandate a finding of willfulness," the Federal Circuit has made it quite clear that a potential infringer with actual notice of a patent has an obligation to take "due care" to avoid infringement. 970 F.2d at 828; see also Crystal Semiconductor Corp. v. TriTech Microelectronics Int'l, Inc., 246 F.3d 1336, 1351 (Fed. Cir. 2001). To discharge this obligation, the accused infringer "usually" must obtain a written opinion of counsel in order to avoid a finding of willfulness. Comark Communications, Inc. v. Harris Corp., 156 F.3d 1182, 1190 (Fed. Cir. 1998); Electro Med. Sys. v. Cooper Life Scis., Inc., 34 F.3d 1048, 1056 (Fed. Cir. 1994); Spindelfabrik Suessen-Schurr v. Schubert \& Salzer Maschinenfabrik AG, 829 F.2d 1075, 1084 (Fed. Cir. 1987) (stating that an opinion of counsel is "normally" required). And in Smith Engineering Co. v. Eisenmann Corp., No. 01-1202, 2002 U.S. App. LEXIS 905 (Fed. Cir. Jan. 17, 2002), the Federal Circuit dismissed the opinion of defendant's engineering department as insufficient in an unpublished disposition.

By contrast, the cases in which the court excuses a failure to obtain an opinion of counsel usually involve a good reason why the accused infringer did not obtain such an opinion. In State Contracting \& Engineering v. Condotte America, 346 F.3d 1057 (Fed. Cir. 2003), for example, the court refused to draw an adverse inference from failure to obtain an opinion of counsel where the defendant, a state contractor, relied upon the state's specific representation that it had a license to use the patented technology.

14. See Eastman Kodak Co. v. Goodyear Tire \& Rubber Co., 114 F.3d 1547, 1561 (Fed. Cir. 1997) ("[F]ailure to introduce an exculpatory opinion of counsel at trial may support an inference that such an opinion was either never obtained or was adverse."); see also Advanced Cardiovascular Sys. v. Medtronic, Inc., 265 F.3d 1294, 1309 (Fed. Cir. 2001) ("A party asserting its attorney-client privilege [with respect to its legal consultations] runs the risk of having the fact-finder draw a negative inference."); L.A. Gear, Inc. v. Thom McAn Shoe Co., 988 F.2d 1117, 1126 (Fed. Cir. 1993) ("We have held that the assertion of privilege with respect to infringement and validity opinions of counsel may support the drawing of adverse inferences."). That presumption can be rebutted in extraordinary circumstances. In Wesley Jessen Corp. v. Bausch \& Lomb, Inc., 209 F. Supp. $2 \mathrm{~d} 348$ (D. Del. 2002), the court credited the company's "reasonable" belief that it had successfully designed around the patent even though it refused to waive privilege and produce an opinion of counsel. 209 F. Supp. 2d at 391. Notwithstanding cases such as Wesley Jessen, the adverse inference is a major roadblock to defendants seeking to prove their good faith. 
to have a strong impact on a jury that has just concluded that the patent is valid and the defendant an infringer. The court has also created a series of rules for determining whether an opinion is competent, the most important of which is that the opinion must be in writing. ${ }^{15}$

Because of these presumptions, any company that receives a letter putting it on notice of the existence of a patent, and anyone that runs across a potentially relevant patent, has an obligation either to stop using the invention or to obtain a competent written opinion of counsel explaining why the patent is invalid or not infringed. These opinions are expensive. Estimates we have heard put the cost at between $\$ 20,000$ and $\$ 100,000$ per patent, and notices of infringement often include more than one patent. ${ }^{16}$ Obtaining opinion letters requires some experience with the patent system. A company that doesn't know the legal rules-doesn't know how to play the game-ignores a threat of infringement at its peril, even if it believes in good faith that the accusation of infringement is frivolous. Worse still, the uninitiated might get a traditional form of legal advice: an honest opinion that acknowledges a risk of infringement. The accused infringer that does this will almost certainly be on the hook for willful infringement if it continues to make, use, or sell the product. A company that knows how to play the game, by contrast, pays its money and requests only a favorable written opinion. Lawyers will generally be able to come up with plausible arguments that the patent is invalid or not infringed. ${ }^{17}$ As long as the client

15. See, e.g., Comark, 156 F.3d at 1191-92 (also discussing competence of legal opinion); Johns Hopkins Univ. v. Cellpro, Inc., 152 F.3d 1342, 1364 (Fed. Cir. 1998) (discussing competence of opinion in detail).

16. Matthew Powers and Steven Carlson independently reported the same estimates. Matthew D. Powers \& Steven C. Carlson, The Evolution and Impact of the Doctrine of Willful Patent Infringement, 51 SYRACUSE L. REV. 53, 102 (2001).

17. There are almost always nonfrivolous arguments of this sort, and opinion counsel will make them because, at the end of the day, opinion counsel are lawyers working for a client and patent issues tend to be issues about which reasonable minds can differ. While the standard for what level of certainty an opinion writer must possess is not crystal clear from the Federal Circuit's pronouncements on the subject, it is obviously not a "you-must-believe-in-your-argument-beyond-a-reasonable-doubt-before-giving-anopinion-to-the-client" standard. In fact, at least some cases suggest that it approaches a Rule 11 standard. See, e.g., Ryco, 857 F.2d at 1428. Patent law is also complex, both factually and legally: over $30 \%$ of district court claim constructions are reversed by the Federal Circuit, to pick just one example. Christian A. Chu, Empirical Analysis of the Federal Circuit's Claim Construction Trends, 16 BERKELEY TECH. L.J. 1075, 1104 (2001) (giving numbers between $30 \%$ and $38 \%$, depending on the measure chosen); see also Kimberly A. Moore, Are District Court Judges Equipped to Resolve Patent Cases?, 15 HARV. J.L. \& TECH. 1, 11 (2001) (finding similar numbers). Given the applicable legal standard and the inherent factual and legal complexity of patent law, it should not be surprising that good opinion counsel can almost always find some basis on which to offer, in 
believes the argument (or says it does), it will be able to avoid liability for willfulness.

Importantly, the doctrine of willfulness is dynamic. The question is not simply what the accused infringer thought when it adopted the technology, but also what it thinks at every moment since that time. An accused infringer that originally acted in good faith becomes a willful infringer upon learning that it is infringing a valid patent at any time, including during litigation. ${ }^{18}$ This means that every company must play the game once it has been notified of a claim of infringement, whether or not it had ever heard of the patent (or the patentee) when it began selling the product.

Patent owners, then, can begin the game by the simple expedient of sending a letter to competitors identifying their patent. ${ }^{19}$ That competitor then generally must pay for a written opinion of counsel in order to avoid a willfulness charge in any subsequent suit. ${ }^{20}$ Obtaining a qualified opinion allows the accused infringer to win the willfulness game, at least temporarily. Because willfulness is considered to be dynamic, the accused in-

good faith, a favorable opinion. In any event, in a dozen years of patent litigation neither we nor anyone with whom we have discussed the issue has ever encountered a case in which the accused infringer did not raise a claim of patent invalidity.

18. Akeva L.L.C. v. Mizuno Corp., 243 F. Supp. 2d 418, 421 (M.D.N.C. 2003) ("[N]either infringement nor the exercise of due care [is] a static concept."). Patent infringement is "a continuing tort, and an action even if innocently begun does not automatically retain its purity as circumstances change." Pall Corp. v. Micron Separations, Inc., 66 F.3d 1211, 1221-22 (Fed. Cir. 1995). As one court put it, an infringer who "continued to sell the infringing [products] after the patent issued, well after it had notice the patent was pending for a particular design, and even after this suit for infringement was filed ... intentionally accepted the risk of infringement." Avia Group Int'l, Inc. v. L.A. Gear Cal., Inc., 853 F.2d 1557, 1566-67 (Fed. Cir. 1988); see also Pacific Furniture Mfg. Co. v. Preview Furniture Corp., 800 F.2d 1111, 1114 (Fed. Cir. 1986) (permitting a finding of willful and deliberate infringement despite knowledge of previous, similar designs that might constitute prior art); Shiley, Inc. v. Bentley Labs., 794 F.2d 1561, 1568 (Fed. Cir. 1986) (permitting a finding of willful infringement even though the accused infringer began marketing the product before the patent ever issued).

19. Because the law imposes a duty of due care to avoid infringement on anyone who is aware of a patent, $R y c o, 857$ F.2d at 1428 , even a letter identifying the patent but not alleging infringement by a specific product may be sufficient to trigger the obligation to obtain an opinion of counsel. Thus, a patentee can impose this burden on a competitor without risking a declaratory judgment suit in return. Legislation under consideration by Congress at the time of this writing would eliminate this incongruity by giving an accused infringer the right to sue for declaratory judgment if a letter triggers a willfulness obligation. See House Panel Explores Proposals to Improve Quality of Issued Patents, 66 PAT., TRADEMARK \& COPYRIGHT J. 406, 408 (2003).

20. Not all defendants obtain advice letters; some may take the chance that the patentee won't actually sue, or that the suit will be unsuccessful. But there are strong incentives to obtain such a letter. 
fringer may need to update the opinion over time and especially during litigation to account for new information. This further increases the cost of the game.

The cycle of threat and opinion letters imposes a deeper cost than just legal fees. Disclosing the opinion of counsel in court necessarily waives the defendant's attorney-client privilege. Part III discusses this waiver in more detail.

\section{THE SCOPE OF PRIVILEGE WAIVER}

There are a variety of ways in which patent courts skin the privilege cat. $^{21}$ There are two distinct axes along which the waiver determination can vary-time and subject matter-and differing points along each axis at which intelligible lines can be (and have been) drawn. While not all courts considering the waiver question have expressly parsed it this way, the arguments underlying the various positions set forth below are the ones courts typically grapple with in making decisions about willfulness and waiver.

\section{A. The Waiver Can Vary by Time}

Courts differ on the temporal extent of the waiver. Some courts have refused to place any time limit whatsoever on the waiver. Others have required waivers that extend until litigation begins, and still others have required waiver of privilege only at the time the written opinion is rendered.

Some courts suggest that the waiver should not be cut off at any point in time, at least in the ordinary case in which the alleged infringement is continuing. ${ }^{22}$ These courts parse willfulness over time and presumably would consider defining some, but not all, infringement by the same defendant as willful, depending on when the defendant acquired knowledge about the patent. So long as the accused infringer chooses to continue engaging in the conduct, its state of mind remains relevant. Just because the accused infringer once had a good faith belief that its conduct was acceptable does not mean that this belief did not change (or should not have

21. For general discussions of the conflicting opinions on the scope of privilege waiver, see Powers \& Carlson, supra note 16, at 85-109; Cecil C. Kuhne, III, The Adviceof-Counsel Defense in Patent Infringement Cases: How Far Does Waiver of Work Product Extend?, 30 PEPP. L. REV. 445 (2003).

22. If the accused infringer ceases the conduct when sued, the fact that it later concludes that it was infringing doesn't mean that it was originally engaged in willful infringement. 
changed) based on new information. ${ }^{23}$ Accordingly, even if the accused infringer adopted the technology in good faith, a decision to continue selling a product once the accused infringer knows it to be infringing is just as culpable as willfully adopting the technology in the first place.

A second set of courts takes a somewhat more limited view of the temporal extent of the waiver. These courts suggest that the waiver should be cut off at the time the lawsuit is filed, at least where the opinion was rendered prior to the filing of the lawsuit. ${ }^{24}$ The argument for this position is that once litigation is underway, the policies underlying the attorneyclient privilege and, perhaps more pertinently, the work product doctrine, overcome the policies regarding the accused infringer's continuing conduct laid out in the preceding paragraph. ${ }^{25}$ These courts don't focus on the policies underlying the willfulness doctrine; from the patent law perspective there seems little reason to distinguish between pre- and postlitigation conduct. Rather, these courts have made a judgment that the policies underlying the attorney-client privilege should outweigh the reasoning of the willfulness doctrine once a lawsuit is filed.

A third set of courts adopts an even more limited view of the waiver, suggesting that the waiver should cut off at the time the written opinion is rendered. ${ }^{26}$ According to this approach, the accused infringer must make a good faith evaluation of its conduct either when it decides to commence potentially infringing activity or when it first decides to continue that activity after becoming aware of the patent and the potential for infringement. The accused infringer can rely on its evaluation at those two points; it does not have to update that evaluation thereafter. It's not clear why this is so. It may be that these courts, like the litigation cutoff courts, are giving the attorney-client privilege precedence over the rationale for willful-

23. See Akeva, 243 F. Supp. 2d at 422-24; Chiron Corp. v. Genentech, Inc., 179 F. Supp. 2d 1182, 1188 (E.D. Cal. 2001).

24. If a patentee sues without first putting the accused infringer on notice, as commonly occurs, see Brooktree Corp. v. Advanced Micro Devices, Inc., 977 F.2d 1555 (Fed. Cir. 1992), litigation will be proceeding while the opinion is obtained. Thus a strict temporal cutoff would be unworkable.

25. Motorola Inc. v. Vosi Techs., Inc., No. 01 C 4182, 2002 U.S. Dist. LEXIS 15655 (N.D. Ill. Aug. 19, 2002); Electro Scientific Indus. v. Gen. Scanning, Inc., 175 F.R.D. 539, 544 (N.D. Cal. 1997); cf. Solaia Tech. LLC v. Jefferson Smurfit Corp., No. 01 C 6641, 2002 U.S. Dist. LEXIS 14562 (N.D. Ill. Aug. 7, 2002).

26. Allergan, Inc. v. Pharmacia Corp., Civ. A. No. 01-141-SLR, 2002 U.S. Dist. LEXIS 19811 (D. Del. May 17, 2002). But see VLT, Inc. v. Artysyn Techs., Inc., 198 F. Supp. 2d 56, 58 (D. Mass. 2002) (drawing a rather artificial distinction between some litigation counsel work product documents and others, and requiring disclosure only of those that might contradict the opinion letter). 
ness law. Alternatively, these decisions may be based on an understanding that companies in reality do not (or ought not be required to) continuously reevaluate their decisions in light of legal concerns. This latter approach is practical because it avoids some of the problems we discuss below, but it provides no good theoretical explanation for why parties shouldn't reevaluate their decisions when faced with new information. ${ }^{27}$

Timing of the waiver is significant to clients because it affects an accused infringer's choice of litigation counsel. Furthermore, it affects the type of advice litigation attorneys feel free to give their clients. While any waiver of privilege will affect decisionmaking at some times, extending the waiver into the litigation process magnifies those effects.

\section{B. The Waiver Can Vary by Subject Matter}

Courts are even more divided over the question of what information must be disclosed when the privilege is waived in patent litigation. There is substantial agreement that a client must disclose other opinions it may have received bearing on the same patents. ${ }^{28}$ The other opinions include, for example, opinions from other counsel, or prior or subsequent opinions from the counsel who wrote the opinion letter, but may not include opinions from trial counsel, as parsed below. Beyond that basic point, opinions vary. Some courts may be inclined to limit waiver to the particular issues addressed in the opinion, for instance, while others will not.

\section{Attorney-Client Versus Work Product Privilege}

One significant subject matter distinction is between material protected by attorney-client privilege and material protected by the attorney work product doctrine. The attorney-client privilege protects only communications between attorneys and clients, while the work product doctrine protects uncommunicated work product created during or in anticipation of litigation.

Some courts suggest that the waiver should be limited to documents of which the client was aware at the time the opinion was rendered (for example, documents given by the client to opinion counsel or by opinion counsel to the client). According to these courts, uncommunicated work

27. Indeed, it seems quite likely that clients do update their preferences as a business matter based on new information, though not always in the continuous way that some courts seem to assume.

28. See, e.g., Allergan, 2002 U.S. Dist. LEXIS 19811 (compelling disclosure of all documents related to opinions in suit). 
product of opinion counsel need not be produced. ${ }^{29}$ Because the willfulness inquiry focuses on the client's state of mind, all that matters is what the client knew. And what the client knew is based upon what counsel communicated to the client. ${ }^{30}$ What else counsel may have known or thought is irrelevant if counsel did not disclose it-unless the opinion looked so slipshod that the client reasonably should have questioned its contents. ${ }^{31}$ Under this limited approach, even drafts of the opinion need not be produced, so long as they were not sent to the client. ${ }^{32}$

Other courts take the broader position that all of opinion counsel's work product should be produced, even if it is not communicated to the client. ${ }^{33}$ A document showing what counsel knew, even if the document itself was not communicated, may bear on what counsel communicated orally, or help a fact finder to infer something about the tenor of counsel's conversations with the client. Such material may also help the patent owner depose opinion counsel, and possibly the client, more thoroughly (for example, by seeking to use the documents to refresh recollections about what may have been discussed orally). Another reason to require disclosure of work product is based directly on the Federal Rules of Civil Procedure: even if all that is relevant to the willfulness inquiry is the infringer's state of mind, discovery is permitted into not just relevant evidence but also into material "reasonably calculated to lead to the discovery of admissible evidence."34 This likely includes uncommunicated memoranda that might provide a basis for questioning counsel or impeaching a witness.

29. See Eco Mfg. v. Honeywell Int'l, No. 1:03-cv-0170-DFH, 2003 U.S. Dist. LEXIS 7257, at *18-24 (S.D. Ind. Apr. 11, 2003); Steelcase Inc. v. Haworth, Inc., 954 F. Supp. 1195, 1198-20 (W.D. Mich. 1997); Thorn EMI N. Am., Inc. v. Micron Tech., Inc., 837 F. Supp. 616, 620-22 (D. Del. 1993).

30. Cf. Thorn EMI, $837 \mathrm{~F}$. Supp. at 620-21. The willfulness inquiry will always extend beyond those communications to some extent. The court will inquire whether counsel was responsibly selected, whether the opinion letter itself is accurate and complete in its recitation of facts known to the client, and whether the letter is facially reasonable and diligent in its legal analysis. Evaluation of these issues will often require some discovery beyond the bare fact of what was communicated to the client.

31. Steelcase, 954 F. Supp. at 1198-99; Thorn EMI, 837 F. Supp. at 622-23.

32. Cf. Cordis Corp. v. SciMed Life Sys., 980 F. Supp. 1030, 1034 (D. Minn. 1997).

33. Akeva L.L.C. v. Mizuno Corp., 243 F. Supp. 2d 418, 425 (M.D.N.C. 2003).

34. FED. R. CIV. P. 26(b)(1); see Beneficial Franchise Co. v. BankOne, N.A., 205 F.R.D. 212, 218 (N.D. Ill. 2001) (discussing waiver of post-suit attorney-client and workproduct privileges); Electro Scientific Indus. v. Gen. Scanning, Inc., 175 F.R.D. 539, 54445 (N.D. Cal. 1997). 


\section{Opinion Counsel Versus Trial Counsel}

Both the communications-only and the work product courts divide on the question of which lawyers must disclose the information in question. Some courts suggest that any documents that are related to the subject matter of the case and in the possession of any counsel, including trial counsel, must be produced. ${ }^{35}$ This view is based on the strongest version of the arguments for continuing willfulness and the relevance of documents in discovery. If willfulness is measured on a continuing basis and if work product can shed light on the substance of oral communications, it may make sense to require disclosure of all communications and all work product on an ongoing basis, even during litigation.

Other courts, by contrast, draw a sharp distinction between communications and work product generated by opinion counsel and that generated by trial counsel. These courts hold that opinion counsel must waive work product and attorney-client privilege but that trial counsel's work product and communications with the client need not be disclosed. ${ }^{36}$ These courts may be motivated in part by a belief that willfulness should depend primarily on decision making by the client at the time the product is adopted. They also observe that the possibility of settlement will be reduced if trial counsel and client cannot candidly discuss the weaknesses in the client's case. $^{37}$

Still other courts have taken a middle position between limiting waiver to opinion counsel and applying it to trial counsel. Some courts exempt documents reflecting the opinion work product of trial counsel from the waiver, in effect requiring disclosure of all communications from all counsel, but work product only from opinion counsel. This position balances full disclosure with the belief that trial counsel in particular must have privacy to prepare effectively for litigation. ${ }^{38}$ Some courts temper this rule by

35. E.g., Akeva, 243 F. Supp. 2d at 422-24; Novartis Pharm. Corp. v. Eon Labs Mfg., 206 F.R.D. 396, 399 (D. Del. 2002); Electro Scientific, 175 F.R.D. at 544.

36. See, e.g., Dunhall Pharm., Inc. v. Discus Dental, Inc., 994 F. Supp. 1202, 1205 (C.D. Cal. 1998) (finding there is a waiver of all pre-suit privileges and post-suit attorney client privilege but no waiver of post-suit work product privilege). This approach necessarily assumes that opinion counsel and litigation counsel are different; these courts would presumably not draw a distinction if a client hired the same lawyer or firm to write the opinion and to litigate the case.

37. For further discussion of this point, see infra notes 61-62 and accompanying text.

38. Here, too, the court presumes that opinion counsel is not also trial counsel; indeed, most courts have endorsed a broad waiver of the attorney-client and work product privileges where the accused infringer used the same firm as both opinion and trial counsel. Dunhall Pharm., 994 F. Supp. at 1205; see also Mosel Vitelic Corp. v. Micron Tech- 
exempting from waiver documents reflecting the opinion work product of trial counsel unless they contradict, cast doubt upon, or are inconsistent with the opinion letter. ${ }^{39}$ This position represents a compromise between the arguments in the two preceding paragraphs.

\section{Implications of the Various Rules}

We take no position here on which of the various positions laid out above is most correct under prevailing law. Our point for purposes of this Article is somewhat different: precisely because there are forceful arguments supporting a variety of positions on the scope of waiver issue, and because there is no Federal Circuit precedent on point, ${ }^{40}$ accused infringers necessarily live in fear and doubt once they make the decision to interpose the "advice of counsel" defense. And because failing to waive the privilege and rely on the opinion of counsel creates an inference that the infringement was willful under current patent law, there are very strong structural incentives to rely on the advice of counsel at trial.

\section{PROBLEMS WITH THE WILLFULNESS GAME}

The waiver of privilege associated with the willfulness game imposes significant costs on accused infringers, and indeed on society more generally. ${ }^{41}$ Most of these costs inhere in the system, regardless of how broadly

nology, Inc., 162 F. Supp. 2d 307, 312-13 (D. Del. 2000); Electro Scientific, 175 F.R.D. at 545; Clintec Nutrition Co. v. Baxa Corp., No. 94-C-7050, 1996 U.S. Dist. LEXIS 4001, at*7 (N.D. Ill. Apr. 1, 1996); cf. Michlin v. Canon, Inc., 208 F.R.D. 172, 174 (E.D. Mich. 2002) (observing that the work product waiver analysis would have been simplified if opinion counsel were not also trial counsel, and rejecting an effort to screen two different lawyers in the same firm from each other).

39. See Beneficial Franchise Co., 205 F.R.D. at 218; Micron Separations, Inc. v. Pall Corp., 159 F.R.D. 361, 365 (D. Mass. 1995).

40. Powers \& Carlson, supra note 16, at 93. While Federal Circuit's expected decision in Knorr-Bremse Systeme Feur Nutzfahrzeuge GmbH v. Dana Corp., 344 F.3d 1336 (Fed. Cir. 2003), may touch on the issue of the scope of privilege waiver, it is unlikely to resolve the issue directly. That court has restricted the scope of its inquiry to the propriety and extent of the current inference of willful infringement when an accused infringer refuses to waive privilege. Dana Corp., 344 F.3d at 1336. It may not tackle the issue of the scope of the privilege waiver at all.

41. We are not the first to criticize the application of the willfulness doctrine, though many commentators focus on aspects other than the ones we discuss. See Robert O. Bolan \& William C. Rooklidge, Imputing Knowledge to Determine Willful Patent Infringement, 24 AIPLA Q.J. 157 (1996); John Dragseth, Coerced Waiver of the AttorneyClient Privilege for Opinions of Counsel in Patent Litigation, 80 MINN. L. REV. 167 (1995); Powers \& Carlson, supra note 16, at 106-12; Edwin H. Taylor \& Glenn E. Von Tersch, A Proposal to Shore Up the Foundations of Patent Law that the Underwater Line Eroded, 20 HASTINGS COMM. \& ENT. L.J. 721 (1998); Shashank Upadhye, Understand- 
the waiver of privilege is interpreted. Naturally, however, the broader the waiver, the more the willfulness game distorts the behavior of lawyers and counsel. These costs fall into five basic categories.

\section{A. Undermining Patent Disclosures}

The first significant cost associated with the willfulness game is its interference with the disclosure function of patent law. Although patent policy presumes that the public learns from patents, the willfulness game creates a strong incentive not to read patents. This problem occurs irrespective of whether any notice letters are ever sent. The mere existence of the willfulness doctrine in its current form means that any time an individual or company learns of a patent that might be relevant to its products, the company is in trouble. No matter how the patent is discovered, the company must spend tens of thousands of dollars to obtain an opinion, then forego some or possibly all of its attorney-client privilege with respect to the evaluation of the patent (and possibly with respect to the eventual litigation concerning it, too). The company would be much better off if it had never encountered the patent.

It's not always possible to remain ignorant, of course. A company that receives a notice of infringement will simply have to play the willfulness game. But companies can also be hooked into the game if their engineers run across patents that seem to cover their technology, either in the course of their scientific reading or because they notice and investigate the patent numbers marked on many products. ${ }^{42}$ Once a company becomes aware of a patent, it has an obligation to obtain a written opinion of counsel or risk later being held a willful infringer. To avoid this significant cost, in-house patent counsel and many outside lawyers regularly advise their clients not

ing Willfulness in Patent Infringement: An Analysis of the "Advice of Counsel" Defense, 8 Tex. Intell. Prop. L.J. 39 (1999). Perhaps the most interesting criticism comes from Alan Herda:

Except for two spiny anteater species found in New Guinea and Australia, the duck-billed platypus is the only mammal that can lay an egg. This makes the duck-billed platypus a strange creation. Likewise, the doctrine of willful patent infringement, as it relates to defending willfulness, is also a strange creation that lays an egg.

Alan N. Herda, Willful Patent Infringement and the Right to a Jury Trial, 9 TEX. WESLEYAN L. REv. 181, 182 (2003). But see Jon E. Wright, Comment, Willful Patent Infringement and Enhanced Damages-Evolution and Analysis, 10 GEO. MASON L. REV. 97 (2001) (defending the current rules).

42. See 35 U.S.C. $\S 287(a)$ (2000) (requiring that patentees mark products with patent numbers in order to recover damages). 
to read patents if there is any way to avoid it. ${ }^{43}$ What you do know will certainly harm you, they reason, so it is generally better not to know. ${ }^{44}$ Thus, from the perspective of a potential infringer, ignorance is bliss.

From society's perspective, however, ignorance is decidedly not bliss. One of the fundamental justifications for the patent system is the dissemination of ideas that would otherwise remain secret. Indeed, courts have gone so far as to hold that "patent rights are given in exchange for disclosing the invention to the public." 45 Many basic rules of patent law are de-

43. See, e.g., Taylor \& Von Tersch, supra note 41 , at 737 ("As matters now stand many companies discourage employees from reading patents. This presumably lessens the chance that the company will be found to have knowledge of a patent. However, this defeats the basic purpose of the patents [sic] laws, dissemination of information."); Dennis Fernandez, Move Over Letterman: Top 10 Most Common IP Management Mistakes for New Companies, Pat. Strategy \& MGMT., July 1, 2003, at 3. ("Additionally, in many cases it may be appropriate for companies, as a matter of policy, to discourage looking at issued patents owned by other entities so as to avoid awareness of potentially infringed patents.").

44. $C f$. Douglas adams, The Restaurant at the End of the Universe 35 (1982) (describing "peril-sensitive sunglasses" that go entirely opaque at the first sight of danger, "and thus prevent you from seeing anything that might alarm you").

45. Festo Corp. v. Shoketsu Kinzoku Kogyo Kabushiki Co., 535 U.S. 722, 736 (2002); see also J.E.M. Ag Supply, Inc. v. Pioneer Hi-Bred Int'l, 534 U.S. 124, 142 (2001) ("The disclosure required by the Patent Act is the quid pro quo of the right to exclude."); Bonito Boats, Inc. v. Thunder Craft Boats, Inc., 489 U.S. 141, $150-51$ (1989); Kewanee Oil Co. v. Bicron Corp., 416 U.S. 470, 481 (1974); W.L. Gore \& Assoc. v. Garlock, Inc., 721 F.2d 1540, 1550 (Fed. Cir. 1983) ("Early public disclosure is a linchpin of the patent system."). Economists and legal scholars have also argued that disclosure is a key function of the patent system. See, e.g., Donald S. Chisum, Anticipation, Enablement, Obviousness: An Eternal Golden Braid, 15 AIPLA Q.J. 57 (1987) (stating that disclosure is "a primary purpose" of the enablement requirement); Suzanne Scotchmer \& Jerry Green, Novelty and Disclosure in Patent Law, 21 RAND J. ECON. 131 (1990) (assessing the costs and benefits of the patent system by relying on the value of disclosure); Manuel Trajtenberg, A Penny for Your Quotes: Patent Citations and the Value of Innovations, 21 RAND J. ECON. 172, 174 (1990) (arguing that the most-cited-and therefore presumably most-read-patents are also the most valuable ones). And, as another astute observer has noted:

Another aspect of what we think of as "the patent" which should not be forgotten is that it is not only a grant of right to exclude from the government; simultaneously, it is a publication, making (in principle at least) a full public disclosure of the invention due to section 112-1. So even if it does not go into the public domain during the patent term, the public gets the advantage of knowing what the invention is and how to practice it. ("Literae patentes" = "open letters," in short form, "patents.") That's my Saturday night lecture.

Janice M. Mueller, A Rich Legacy, 14 BERKELEY TECH. L.J. 895, 900 (1999) (quoting email from Judge Giles Rich, Circuit Judge, Ct. of App. for the Fed. Cir., to Janice Mueller, Assistant Professor, The John Marshall Law School (Sept. 6, 1998)). 
signed with an eye toward making sure that the patentee discloses her invention to the public and that the public gets the benefit of that disclosure. Most obviously, the patent system promotes this goal by requiring that every patentee describe her invention in such "full, clear, concise and exact terms" as to enable anyone of ordinary skill in the art to make and use the invention. ${ }^{46}$ In addition, the rules of priority and statutory bars serve the disclosure function by encouraging inventors to forego trade secret protection in favor of patents and file for patent protection early. ${ }^{47} \mathrm{By}$ waiting too long to file a patent application or inventing without giving the world the benefit of the invention, inventors lose not only their own rights to file for a patent but also the ability to prevent a second inventor who does give the world the benefit of the invention from obtaining her own patent. ${ }^{48}$ All of these rules presuppose that potential infringers actually read the patent disclosure. If they don't, and instead take their lawyers' advice and avoid patents in order to escape the taint of willfulness, the patent system's goal of disclosure is frustrated. The fact that the patent system discourages searching for prior patents contrasts starkly with trademark law, which premises willfulness in part on a failure to search for prior marks, considering that failure a form of willful blindness. ${ }^{49}$

\section{B. A Trap for the Unwary}

As noted above, experienced patent lawyers often advise their clients to avoid reading patents in order to avoid liability for willfulness. However, not all clients will get—or follow—such advice. Companies without patent counsel or with little exposure to the patent system might naïvely assume that it is a good idea to read patents to see what is out there before inventing, or even while bringing to market a product they already have invented but which could be improved. Others might not heed their lawyers' advice or, more likely, might be unable to do so. A company with

46. 35 U.S.C. $\S 112$ \ $1(2000)$.

47. See id. $\S 102$ (b) (barring a patent if the application is filed more than a year after the inventor's publication or commercial activity); id. $\S 102(\mathrm{~g})$ (refusing priority in a patent dispute to one who has "abandoned, suppressed or concealed" the invention).

48. This results from judicial interpretation of 35 U.S.C. $\S 102(b)$. See 35 U.S.C. $\S 102$ (g) (denying prior art status to inventions that have been "suppressed" or "concealed"); W.L. Gore \& Assoc., 721 F.2d at 1549-50 (holding that commercial but secret prior use by a third party does not constitute prior art sufficient to bar a second inventor from patenting the invention). As a result, courts have granted patents to second developers who, unlike the true inventor, gave the public the benefit of the invention by disclosing it in a patent. See Gillman v. Stern, 114 F.2d 28, 30 (2d Cir. 1940); MARK A. LEMLEY ET AL., SOFTWARE AND INTERNET LAW 201-03 (2d ed. 2003).

49. Int'I Star Class Yacht Racing Ass'n. v. Tommy Hilfiger U.S.A., 146 F.3d 66, 71 n.2 (2d Cir. 1998). 
ten thousand employees will find it hard to police the behavior of its engineers. Even if the company were to engage in an education program ("Stop! Don't read that patent!"), it is quite likely that some engineers will run across patents in the course of their work and read them. Because these engineers may not know they are doing anything of legal significance, they are unlikely to do what the patent willfulness game demandsimmediately seek a written opinion of counsel. And if the engineers have read patents and the company has not obtained the advice of counsel, the company is presumptively a willful infringer under existing Federal Circuit precedent. That precedent draws an inference of willfulness from the failure to obtain and disclose a written opinion of counsel in litigation. ${ }^{50}$ The existence of the willfulness game thus serves as a trap for the unwary. No matter how hard a company tries, there will likely come a day when the behavior of its engineers makes it liable for willfulness.

\section{Polluting Pre-Litigation Advice}

Even for those companies sophisticated enough to be aware of the willfulness game, the existence of the game distorts legal advice. The Federal Circuit's legal rules regarding disclosure of opinions of counsel box companies who seek legal advice into a corner. If a company does not obtain a written opinion of counsel, it is presumed to be a willful infringer. ${ }^{51}$ If the company obtains an opinion of counsel but doesn't waive privilege in order to disclose that opinion once litigation ensues, the court will infer that the opinion was adverse to the company's interests, and once again presume that it was a willful infringer. ${ }^{52}$ Since companies know they will have to disclose the opinions they obtain, they place a heavy premium on obtaining a written opinion of counsel that is favorable to them-one that concludes that the patent is invalid, not infringed, or both. Indeed, the importance of the letter reading favorably for the accused infringer's case is so great that no competent patent counsel would send written advice to a client with the bad news that they likely infringe a valid patent except under extraordinary circumstances. Opinion letters often simply remain silent on issues where the news is not good, occasionally opining only on noninfringement and ignoring validity.

50. See cases cited supra note 13. The Federal Circuit has agreed to reconsider this practice en banc. Knorr-Bremse Systeme Feur Nutzfahrzeuge GmbH v. Dana Corp., 344 F.3d 1336 (Fed. Cir. 2003).

51. See supra note 14 and cases discussed therein.

52. See Eastman Kodak Co. v. Goodyear Tire \& Rubber Co., 114 F.3d 1547, 1561 (Fed. Cir. 1997) ("[F]ailure to introduce an exculpatory opinion of counsel at trial may support an inference that such an opinion was either never obtained or was adverse."). 
Opinions of counsel, in short, aren't unvarnished legal advice. They exist for show. ${ }^{53}$ The fact that the pre-litigation advice a client receives is skewed so heavily in favor of the client's public position undermines the real value of legal advice. A company facing the threat of patent litigation-or even one that stumbles across a relevant patent-would like to know what its realistic chances are of prevailing in a lawsuit. In our experience, clients often ask lawyers for odds on who will win a suit. To make an informed decision about whether to take a license, change the product, or risk infringement liability, companies must be able to rely on their lawyers to provide honest advice that explains where the company is vulnerable and which arguments are strong.

But honest advice is precisely what the willfulness game discourages. Clients instead get opinions of counsel written with litigation in mind. If they believe those written opinions, they are more likely to litigate cases they should settle based on unduly optimistic advice. ${ }^{54}$ Or they may ignore the opinions, treating them as the advocacy showpieces they often are, in which case they must make their own assessment of their litigation prospects without the aid of their lawyers. Neither outcome is conducive to good business decision making.

There is a third possibility, perhaps the most realistic as a practical matter. Patent lawyers may write one thing down and tell the client something different orally. This is a dodge that seems to give the client what it wants - accurate legal advice-without exposing the client to liability. But it is problematic for a number of reasons. Most obviously, it puts the lawyer in a compromising position once the privilege is waived. After providing contradictory oral advice, the lawyer will either have to lie on the stand or to testify truthfully and undermine the client's argument that the

53. The Federal Circuit has tried to cabin this practice by permitting a fact-finder to disregard an opinion "written in anticipation of litigation" rather than as part of genuine advice. Therma-Tru Corp. v. Peachtree Doors, Inc., 44 F.3d 988, 997 (Fed. Cir. 1995). This merely completes the Catch-22 of the court's willfulness game. All opinion letters are written in anticipation of litigation; no client who really wanted legal advice rather than a willfulness defense would play the elaborate game the court has created.

54. A related problem concerns non-litigation uses of patent opinions. One experienced opinion drafter who investigated what uses were made of opinion letters told us that more than half of opinions were ultimately used not in litigation, but in connection with venture financing or acquisition-related due diligence. We have some privilegerelated concerns about sharing such a letter with outside financiers. But even leaving those concerns aside, the willfulness game means that venture capitalists and acquirers doing due diligence are relying on opinion letters that don't accurately reflect the likely outcome of patent litigation. The distortion of financier decisionmaking is a further social cost to the willfulness game. 
opinion letter served as the basis of a good faith belief in noninfringement. Lawyers may refuse to give oral advice that undercuts a letter or may shade that advice in order to avoid finding themselves in such a situation. In addition, oral advice is harder to communicate within a client company, and may have less force with a company's board of directors than a written opinion of counsel. This sort of duplicity represents an imperfect workaround from the client perspective. It is also unethical. Feasible workaround or not, it is hardly the sort of behavior the legal system should encourage.

\section{The Choice of Counsel}

The impact of the waiver of privilege not only affects legal advice, but also affects the choice of litigation counsel. ${ }^{55}$ As noted in Part III, courts are sharply divided as to the scope of the waiver of privilege resulting from the decision to disclose an opinion of counsel. ${ }^{56}$ While some courts limit the scope of the waiver to the opinion itself and communications that surround it, other courts go further. They may permit discovery into the communications between litigation counsel and the client about issues considered in the opinion of counsel on the theory that those communications offer insight into whether the client continues to believe the opinion as litigation proceeds. ${ }^{57}$ Some courts go further still, permitting discovery not only of communications between litigation counsel and the client but also of the litigation attorney's work product. ${ }^{58}$ This broad reading of the privilege waiver is a disaster for litigators. It may force lawyers to turn over "smoking gun" memos involving the weaknesses in their case. Lawyers will have to sort their files and permit the other side access to at least part of those files.

The waiver of privilege gives smart clients a strong incentive to hire different lawyers at different law firms to do their opinion and litigation work. First and most obviously, because the client has no real choice but to waive privilege, it is a singularly bad idea to hire the same lawyer to write the opinion and litigate the case. That lawyer will end up on the stand, making it difficult to prepare and litigate the case and undermining his credibility with the jury. His communications with the client will also

55. The willfulness rules may also affect the choice of opinion counsel. Court decisions have set out guidelines for what constitutes a competent opinion of counsel, and those opinions strongly emphasize the importance of hiring lawyers with patent expertise. See Acoustical Design, Inc. v. Control Elecs. Co., 932 F.2d 939, 942 (Fed. Cir. 1991). These guidelines do affect the choice of counsel, but in a way that seems unobjectionable.

56. See supra notes 21-40 and accompanying text.

57. See cases cited supra note 25 .

58. See cases cited supra note 26 . 
be subject to discovery and cross-examination - an experience that can be embarrassing at best and undercut the case at worst. Even if a different lawyer at the same firm litigates the case, that lawyer's obligation to examine and defend other attorneys at the firm can create problems. More importantly, some courts have drawn a line between opinion counsel and litigation counsel, requiring waiver of attorney-client privilege from the firm that prepared the opinion but not extending waiver beyond that firm. ${ }^{59}$ In these courts it is particularly important that a client separate litigation counsel from opinion counsel in order to insulate litigation counsel from the problems of privilege waiver.

Our firm performs only litigation, not opinion work, and so we may actually benefit from the effective disqualification of patent firms that do opinion work from subsequent litigation work. But we do not think this disqualification is good for clients. Companies often have existing relationships with counsel whom they trust, and they may be quite surprised to learn that by turning to those lawyers for advice they have made it more difficult to rely on them in litigation. Hiring a second lawyer and bringing her up to speed involves some duplication of effort. Particularly in smaller cases, clients may resent being told by a newly-hired lawyer that the first thing they need to do is hire a second lawyer to do much the same investigation. Finally, some clients, particularly those without substantial experience with the willfulness game, will make the mistake of not hiring separate counsel, putting those clients at a significant tactical disadvantage in litigation. The willfulness game thus distorts the client's freedom to choose counsel.

\section{E. Polluting Litigation Advice and Settlements}

The distortions imposed by the willfulness game do not end once litigation begins. Because the court considers willfulness on an ongoing basis, the relevant question is not merely what the client believes at the time it learns of the patent, but whether that belief changes over time. And often it will. Opinion counsel necessarily conducts only a relatively quick, limited investigation into validity and infringement. By contrast, litigation counsel takes a more comprehensive approach once a lawsuit is filed. (Recall that an expensive opinion may cost $\$ 100,000$. A moderately expensive litigation may cost forty times that.) With such further investigation, new arguments will develop and others will look less attractive. This is particularly true once the district court judge construes the patent claims ${ }^{60}$ because the way the claims are interpreted may well foreclose arguments on

59. See cases cited supra notes 39-40.

60. See generally Markman v. Westview Instruments, Inc., 517 U.S. 370 (1996). 
which the opinion substantially relied. Further, the Federal Circuit may well have changed the governing legal rules since the opinion was written. In extreme cases, clients must obtain an entirely new opinion of counsel based on the new information or legal developments.

Because willfulness is an ongoing inquiry, litigation counsel must be careful not to do or say anything to undermine the client's confidence in opinion counsel's written opinion. If something undermines the client's confidence, the client can no longer rely on that opinion in good faith. As a result, litigation counsel may be reluctant to tell the client anything that undermines the written opinion. Litigation counsel may feel constrained to make arguments that aren't likely to win, simply because the written opinion relied on them. Similar to the problems with pre-litigation advice, litigators may not be able to tell clients the unvarnished truth, which may affect their ability to litigate cases effectively. Indeed, in some cases litigators tell their in-house legal counterparts of problems with the case, but then make it clear that in-house counsel can't share those problems with the ultimate decisionmakers, because if the ultimate decision maker knew of the problems that knowledge would undermine the company's confidence in the opinion letter. ${ }^{61}$ The problem is particularly acute in settlement discussions. To settle a case, litigators must be able to convince the client of the weaknesses in its own case. But doing so may undermine the opinion letter and leave the client with the problem of willfulness liability if the case doesn't settle. When litigators can't tell the client about the shortcomings of the case, or if they can tell the inside counsel but not the ultimate decision maker, cases become much harder to settle before trial.

Courts have sought to mitigate the harms of the waiver of privilege by bifurcating the willfulness and infringement inquiries, either by staying willfulness discovery (and therefore necessarily bifurcating the issues at trial) until the jury has found that a valid patent was infringed, or by permitting discovery to proceed but bifurcating the issues at trial. ${ }^{62}$ If willful-

61. It is the company decision makers that must ultimately have a good faith belief in order to avoid infringement.

62. The Federal Circuit has indicated that a bifurcated trial, at least, is the preferred approach to the "dilemma" of an accused infringer who must choose between asserting the privilege and defeating willfulness. Quantum Corp. v. Tandon Corp., 940 F.2d 642, 643-44 (Fed. Cir. 1991). Although the court strongly suggested trial bifurcation, it refused to require it. $l d$.

In our experience, courts do not have a uniform practice as to staying or not staying willfulness discovery, and a significant number of courts do not stay such discovery. Compare Plasmanet, Inc. v. Apax Partners, No. 02 Civ. 9290 (BSJ) (THK), 2003 U.S. Dist. LEXIS 13533 (S.D.N.Y. Aug. 5, 2003) (bifurcating and staying), with Dents- 
ness is tried at a separate time and no discovery into the opinion of counsel is taken unless and until the patent is found valid and infringed, the accused infringer will be able to litigate the underlying case without the inconvenience of having counsel subject to discovery. But bifurcation is far from a perfect solution, especially where only trial is bifurcated and discovery is not stayed. Bifurcating the trial but keeping discovery comprehensive does not do away with the problem of privilege waiver and the resulting tendency to skew legal advice; it just delays the problem. Counsel who know they may well be required to turn over their files will still be careful not to say or do anything that would ultimately undermine their client's willfulness case. Nor does bifurcation solve any of the other problems associated with the willfulness game.

Bifurcation may also be impractical. ${ }^{63}$ Courts already require bifurcation and sometimes trifurcation of antitrust counterclaims, ${ }^{64}$ and some bifurcate damages from liability. ${ }^{65}$ Since virtually every case involves a willfulness claim, requiring bifurcation of such claims would threaten to divide every patent case into three, four, or even five separate trials. Further, to be effective, willfulness bifurcation must delay discovery until after the first trial ends. This means that the court will have to select a new jury to try the willfulness issue. Doing so not only imposes administrative costs - the second jury will have to be brought up to speed on the facts of the case-but also presents potential Seventh Amendment problems. ${ }^{66}$

ply Int'l, Inc. v. Great White, Inc., Civ. A. No. 1:CV-99-1346, 2000 U.S. Dist. LEXIS 13108 , at *9 (M.D. Pa. Sept. 1, 2000) (refusing to stay discovery).

63. See Akeva L.L.C. v. Mizuno Corp., 243 F. Supp. 2d 418, 421 n.4 (M.D.N.C. 2003) (criticizing bifurcation as impractical); F\&G Scrolling Mouse, LLC v. IBM Corp., 190 F.R.D. 385 (M.D.N.C. 1999) (same).

64. See Hunter Douglas, Inc. v. Comfortex Corp., 44 F. Supp. $2 d 145$ (N.D.N.Y. 1999) (ordering trifurcation); 1 HERBERT HOVENKAMP ET AL., IP AND ANTITRUST $\S 11.3 \mathrm{b6}(\mathrm{B})$ (Supp. 2003) (discussing bifurcation of antitrust claims).

65. See, e.g., Plasmanet, 2003 U.S. Dist. LEXIS 13533, at *6 (discussing "a line of cases which recognizes that patent cases are particularly amenable to bifurcation on issues of liability and damages").

66. The Reexamination Clause of the Seventh Amendment prevents a jury from reexamining facts already found by the first jury. See, e.g., Patrick Woolley, Mass Tort Litigation and the Seventh Amendment Reexamination Clause, 83 IOWA L. REV. 499 (1998). It is hard to see how a willfulness jury could avoid injecting its own view of validity and infringement into the determination whether the accused infringer had a good faith belief that the patent was invalid or was not infringed.

This problem would be avoided if there were no right to a jury trial on willfulness. Alan Herda has argued that there is such a right, however. Herda, supra note 41 , at 182. 


\section{WHAT IS TO BE DONE ${ }^{67}$}

The present structure of the willfulness doctrine distorts legal advice, interferes with settlements, and frustrates the disclosure function of the patent system. There are several possible solutions to these problems. These options are abolishing willfulness altogether, eliminating the requirement that accused infringers disclose opinions of counsel, and changing the way willfulness is defined. In our view, the last approach, while far from a perfect solution, best comports with the policies of patent law while preserving the policies underlying the attorney-client privilege.

\section{A. Abolishing Willfulness}

The simplest way to solve the problems described in the previous section would be to abolish the doctrine of willfulness altogether. Without the fear of treble damage liability for willful infringement, companies would have no reason to disclose their opinions of counsel, and hence no obligation to waive the attorney-client or work product privileges. ${ }^{68}$ As a result, they could make informed decisions in reliance on the unbiased advice of counsel without worrying about disclosing that advice in open court. They would be free to use the same lawyer to provide advice and to litigate the case, eliminating wasteful duplication of effort. And they would have no reason to discourage their engineers from reading patents in order to learn either of technical advances or possible legal impediments to a particular project. Furthermore, because the law of willfulness is entirely a judicial creation, courts could arguably modify or abolish it without waiting for Congress to legislate. ${ }^{69}$

Abolishing the willfulness doctrine altogether, however, could create two related problems. First, patentees could be undercompensated: if they recover only their lost profits or a reasonable royalty (of which more be-

67. With apologies to V.I. Lenin.

68. Patent infringement is a strict liability offense. Fla. Prepaid Postsecondary Educ. Expense Bd. v. College Savings Bank, 527 U.S. 627, 646 (1999) (holding patent infringement does not require proof of intent to infringe). This means that proving innocent development or good faith belief in the invalidity of a patent will not protect an accused infringer from liability. All it does under current law is preclude enhanced damages for willful infringement.

69. The patent damages statute provides for enhanced damages beyond lost profits or a reasonable royalty, but makes no mention of willfulness. 35 U.S.C. $§ 284$ (2000). If willfulness were to be abolished, that statute might be rendered a nullity unless there were other cases in which courts might enhance damages. The obvious alternative to willfulness for enhanced damages is a case in which the statutory remedy undercompensates for the infringement. 
low), they are still worse off by at least the amount of legal fees they have expended to obtain those remedies.

Second, abolishing willfulness damages entirely could create problematic incentives for companies that are considering infringing. The remedies for ordinary patent infringement include a permanent injunction to prevent future infringement and damages designed to compensate the patent owner for past infringement. ${ }^{70}$ Those damages are calculated as the greater of the patentee's lost profits or a reasonable royalty for the defendant's use. ${ }^{71}$ Proving lost profits is rather difficult in patent cases, however. The patentee must make a detailed economic showing of demand for the patented good, the absence of noninfringing substitutes, evidence that the patentee would have made the sales if the defendant had not (taking into account the patentee's capacity to produce the products), and the profit the patentee makes per unit. ${ }^{72}$ Courts require sophisticated economic analysis of how the price of a good would have interacted with the quantity sold in the absence of infringement and will not award lost profits from eroded prices without substantial economic evidence. ${ }^{73}$ And for one significant class of patentees-patentees that do not manufacture the patented product, but merely license the technology-lost profits will never be available. ${ }^{74}$ The result is that even some patentees that compete directly with infringers will not be able to show lost profits and will receive only a reasonable royalty as compensation for infringement.

70. Id. $\S \S 283-284$ (providing respectively for injunction and damages). Preliminary injunctions are sometimes available in patent cases, but the standards for granting such injunctions are high and so they are quite rare today. See Amazon.com, Inc. v. Barnesandnoble.com, Inc., 239 F.3d 1343, 1365-66 (Fed. Cir. 2001) (reversing grant of preliminary injunction where there was any serious question whether the patent was valid).

71. 35 U.S.C. $\$ 284$. For a discussion and critique of patent damages rules, see Roger D. Blair \& Thomas F. Cotter, Rethinking Patent Damages, 10 TEX. INTELL. ProP. L.J. 1 (2001).

72. See Panduit Corp. v. Stahlin Bros. Fibre Works, Inc., 575 F.2d 1152, 1158 n.5 (6th Cir. 1978) (setting out the standard test for proof of lost profits in patent cases).

73. See, e.g., Crystal Semiconductor Corp. v. TriTech Microelectronics Int'l, Inc., 246 F.3d 1336, 1358-60 (Fed. Cir. 2001) (emphasizing need for economic analysis of how markets would react to patented technology); Grain Processing Corp. v. Am. Maize Prods. Co., 185 F.3d 1341, 1356 (Fed. Cir. 1999) (demanding "reliable economic proof" that the patentee would have made the sale but for the infringement, considering both the price that would have been charged and the possibility that the infringer might shift to a noninfringing substitute).

74. This is because they will not be able to show that they would have made the infringer's sales themselves but for the infringement, as the lost profits law requires. Amstar Corp. v. Envirotech Corp., 823 F.2d 1538, 1542-43 (Fed. Cir. 1987). 
The fact that damages in many patent cases will be limited to a reasonable royalty creates problems of deterrence. Specifically, it may underdeter willful infringers. A reasonable royalty is the amount an accused infringer would have had to pay the patentee to license the patent in the first place. In the absence of treble damages for willful infringement, if a company knows that retroactively paying a reasonable royalty is the worst that will happen if it is found to infringe, it may be more willing take its chances in court. ${ }^{75}$

This is not to say that patent law would provide no deterrence if willfulness damages were abolished altogether. The court will generally set the royalty at a somewhat higher rate than the parties would have bargained for ex ante because the jury has determined that the patent is valid and infringed. ${ }^{76}$ Further, the prospect of paying $\$ 2$ million or so in legal fees may provide additional deterrence. ${ }^{77}$ And most importantly, infringers generally will not want to make substantial investments in assets specific to the infringing technology if they know that they will ultimately be enjoined from using that technology after trial. While patent litigation takes a very long time- the average patent case that goes to court is decided 8.6 years after the patent is issued ${ }^{78}$ - and a significant number of patents are

75. Willful infringers may also be motivated by the prospect that they can escape personal liability through the limited liability rules of corporation law, and that the corporation itself may be able to enter bankruptcy and avoid its debts. But trebling damages won't solve these problems.

76. See, e.g., Fromson v. Western Litho Plate \& Supply Co., 853 F.2d 1568, 1576 (Fed. Cir. 1988); Stickle v. Heublein, Inc., 716 F.2d 1550, 1563 (Fed., Cir. 1983); Panduit, $575 \mathrm{~F} .2 \mathrm{~d}$ at 1158 ("The setting of a reasonable royalty after infringement cannot be treated ... as the equivalent of ordinary royalty negotiations among truly 'willing' patent owners and licensees. ... [T] he infringer would have nothing to lose, and everything to gain if he could count on paying only the normal, routine royalty non-infringers might have paid."). This may be a significant difference. As Carl Shapiro points out, a patent does not itself confer a right to exclude competitors but merely a right to try to exclude them. Carl Shapiro, Antitrust Limits to Patent Settlements, 34 RAND J. ECON. 391 (2003). Ex ante royalty negotiations will take into account the possibility that a patent will be held invalid or not infringed. A royalty agreement over a valid, infringed patent will tend to produce a significantly higher royalty rate.

77. See Am. Intell. Prop. Law Ass'N (AIPLA), 2003 RePort of the ECONOMiC SURVEY 22 (2003) (surveying members and reporting the cost of patent litigation to average $\$ 2$ million where $\$ 1-25$ million was at stake in the case, and nearly $\$ 4$ million where more than $\$ 25$ million was at stake). In large patent cases fees and costs may exceed those estimates substantially.

78. See John R. Allison \& Mark A. Lemley, Empirical Evidence on the Validity of Litigated Patents, 26 AIPLA Q.J. 185, 236 tbl.12 (1998). 
invalidated in court, ${ }^{79}$ cases involving deliberate copying of a patent will likely be resolved more quickly than average. These cases will also more likely be resolved in the patentee's favor, all other things being equal, unless all of the defendant's significant witnesses are willing to lie and able to do so convincingly. The risk of being shut down by an injunction that will render a defendant's manufacturing investments useless may be a powerful reason not to infringe. ${ }^{80}$

Still, were willfulness to be abolished altogether, it seems likely that companies would, at the margins, be more willing to infringe a patent. Particularly where a patent is in the last half of its term, companies might take their chances that 1) the court will strike down the patent, 2) the patent term will end before the case does, preventing the court from issuing an injunction, or 3) the benefits of having been in the market during the pendency of the lawsuit are worth any damages.

This will be particularly true for those defendants who know they are copying from a patentee that does not manufacture products based on the patent, as those defendants know for sure they will owe only a royalty and not their victim's lost profits. It is worth noting that non-manufacturing patent owners may not be the inventors the system has the strongest interest in protecting. While some inventors may have perfectly legitimate reasons for not manufacturing their inventions (such as individuals or small companies without the resources to devote to building a physical plant), the wide availability of venture capital means that, in most industries, a patentee who wants to enter the market can find a way to do so. Accordingly, many non-manufacturing owners are holdup artists or "trolls" who are in the business of litigation, not innovation. ${ }^{81}$ Arguably these trolls contribute little or nothing to society, while substantially increasing the social costs of the patent system. ${ }^{82}$ A number of commentators have suggested that patent law should give less protection to non-manufacturing

79. Id. at $205-06$ (finding that $46 \%$ of all litigated patents were invalidated); Kimberly A. Moore, Judges, Juries and Patent Cases: An Empirical Peek Inside the Black Box, 99 MiCH. L. REV. 365, 385-86 (2000) (finding that patentees lose 42\% of the subset of cases that make it as far as trial).

80. See Robert Patrick Merges \& John Fitzgerald Duffy, Patent Law and POLICY 1079 (3d ed. 2002) (making this point).

81. The most notorious such patent owner was Jerome Lemelson, who extracted more than $\$ 1$ billion in royalties from his $500+$ patents without ever making a product. See Mark A. Lemley \& Kimberly A. Moore, Ending Abuse of Patent Continuations, 84 B.U. L. REV. (forthcoming 2004) (discussing abuse of the patent system by Lemelson and others).

82. See id.; Michael J. Meurer, Controlling Opportunistic and Anti-Competitive Intellectual Property Litigation, 44 B.C. L. REV. 509 (2003). 
patent owners than it currently does. ${ }^{83}$ Abolishing willfulness altogether might serve that goal by rewarding patentees who participate in the market, and therefore can claim lost profits, while giving less relief to other patentees. Limiting non-manufacturing patent owners to such a remedy would effectively create a doctrine of "efficient infringement," permitting more efficient companies to infringe and pay damages that amount to less than the profit they can make by infringing. ${ }^{84}$

In sum, while the possibility of treble damages for willful infringement provides some additional deterrence to unscrupulous copyists who might otherwise decide to infringe a patent deliberately, there are other significant incentives that deter copying, and the current system may provide the greatest marginal protection to those patentees who are least worthy of such help. We will return momentarily to the question of how optimally to deter deliberate copyists while minimizing the damage to the disclosure goal of patent law. ${ }^{85}$

\section{B. Eliminating the Requirement to Waive Privilege}

If we keep the doctrine of willfulness, a second possibility is to abolish the effective requirement that accused infringers obtain and then disclose a written opinion of counsel. As we explained in Part III, companies do this because patent law permits fact finders to infer willfulness from failure to obtain an opinion of counsel, and further permits them to infer that an opinion was adverse if it was obtained but was not disclosed. Since, as we noted in Part IV.B, essentially all written opinions obtained by companies facing a charge of infringement are favorable, accused infringers generally decide to disclose the opinion rather than have the court draw an adverse inference that is almost certainly factually incorrect. ${ }^{86}$ The inference, then,

83. See, e.g., Michelle Armond, Comment, Introducing the Defense of Independent Invention to Motions for Preliminary Injunctions in Patent Infringement Lawsuits, 91 CaLIF. L. ReV. 117 (2003); Julie S. Turner, Comment, The Nonmanufacturing Patent Owner: Toward a Theory of Efficient Infringement, 86 CALIF. L. REV. 179 (1998).

84. See Shapiro, supra note 76 , at $392-93$ (arguing that infringement by a more efficient company is likely if damages are not multiplied).

85. See infra notes 102-105 and accompanying text.

86. While it is certainly possible that defendants who wish to withhold an opinion of counsel do so because they have received the rare negative opinion letter, it is far more likely that they are reluctant to disclose the opinion either because they don't wish to waive the privilege, or because the opinion, while favorable, is obsolete in view of subsequent discovery, prior art searches, or claim construction rulings.

One common reason for wanting to withhold even a favorable opinion is that the arguments counsel wants to make at trial contradict those made in the opinion. For example, an opinion letter might interpret the claims of a patent narrowly in concluding that there is no infringement, while at trial the accused infringer might want to forego that 
isn't really a reasonable estimate of the facts, but rather a threat designed to force the disclosure of information the accused infringer would rather not give up. And it is a threat that would be inconceivable in other areas of litigation. For instance, no court would infer from a party's failure to call an expert witness that the party must have hired an expert who gave a negative opinion.

As a result of these concerns, some have suggested that the solution to the willfulness game is to eliminate the inferences the courts draw from an accused infringer's failure to obtain or disclose a written opinion of counsel. ${ }^{87}$ The Federal Circuit sitting en banc has taken a case that directly presents these issues. ${ }^{88}$ Eliminating the adverse inference from nondisclosure may give accused infringers greater freedom of action. They will be somewhat less likely to rely on the opinion of counsel and thereby suffer a waiver of the attorney-client privilege, particularly in cases pending before a court that reads the scope of the privilege waiver broadly. Accordingly, accused infringers will have more freedom to choose counsel without worrying about disqualification, and to obtain accurate legal advice during litigation. Eliminating the adverse inference from failure to obtain an opinion at all would also ameliorate the problems of skewed pre-litigation advice and the trap awaiting those unaware of the requirement. ${ }^{89}$ And it seems consistent with our treatment of willfulness in other areas of law. Criminal law and intentional torts likewise inquire into the defendant's state of mind but, unlike patent law, do not require the defendant to waive the attorney-client privilege.

infringement defense because a broader understanding of the patent would render it invalid in light of newly discovered prior art not available to the lawyer who wrote the opinion.

87. See Powers \& Carlson, supra note 16, at 108; M. Patricia Thayer \& Elizabeth A. Brown, Tendering Advice of Counsel In Patent Litigation: Damned If You Do, Damned If You Don't, 3 SEDONA CONF. J. 111 (2001), available at http://www.hewm.com/use/ articleDetails.asp?articleID $=745$. The American Intellectual Property Law Association has taken this position, for example. Brief for Amicus Curiae American Intellectual Property Law Association at 7-10, Knorr-Bremse Systeme Feur Nutzfahrzeuge GmbH v. Dana Corp., 344 F.3d 1336 (Fed. Cir. 2003) (en banc) (No. 01-1357).

88. Knorr-Bremse Systeme Feur Nutzfahrzeuge GmbH v. Dana Corp., 344 F.3d 1336 (Fed. Cir. 2003) (en banc).

89. Neither approach would encourage competitors to read patents, however, because they would still risk treble damages liability by doing so. Only abolishing willfulness outright would do that. Eliminating the inferences would reduce the cost of learning about a patent, however, by removing the privilege waiver risk and possibly by removing the need for a written opinion altogether. They may therefore make it somewhat more likely at the margins that lawyers will countenance their clients reading patents. 
However, while eliminating the adverse inference from failure to disclose an opinion of counsel may be a good idea, ${ }^{90}$ it is unlikely to solve the problems of privilege waiver in more than a few cases. Unlike the ordinary criminal or tort case, there is no question in the average patent willfulness dispute about whether the defendant was aware of the patent and is making the product in question. Rather, the disputed issues are whether the patent is valid and the defendant's product infringes it. Even in the absence of a legal instruction to presume willfulness, the trier of fact is likely to presume willfulness as a factual matter. This is because the very same trier of fact will just have ruled against that defendant at trial on both validity and infringement. ${ }^{91}$ The defendant's best hope of avoiding liability for willfulness is to rely on the advice of counsel. As a result, even without the coercive pressure of the adverse inference, many accused infringers will want to disclose a favorable opinion letter and, accordingly, will have no choice but to waive privilege.

\section{An Objective Standard}

Doug Lichtman has suggested to us that many of the problems of willfulness could be solved if willfulness were tested objectively rather than subjectively. Under this approach, it would not matter whether an accused infringer who was aware of a patent actually believed that the patent was valid and infringed, only what a reasonable person in the accused infringer's position would have thought was relevant. Replacing the current

90. We are less persuaded that the court should reverse the adverse inference it draws when a company that learns of a patent fails to obtain guidance from counsel at all. While eliminating this inference would obviously have some substantial benefits, as noted in text, a company that is aware of a patent but makes its own decision to build a product without legal advice seems to us to be acting at least recklessly, if not willfully. Patent law is an arcane subject full of counterintuitive rules and not easily accessible to laymen. An engineer's rough sense that the patent is obvious or that what she is doing is different enough may not have any actual basis in patent law. We would, therefore, be inclined to treat the failure to obtain legal advice as evidence of willfulness, though not determinative evidence.

91. This is necessarily the case in any willfulness dispute, since willful infringement presupposes infringement of a valid patent. Sometimes the questions will be determined by the factfinder at the same time, and sometimes sequentially, however. See supra notes 62-66 and accompanying text (discussing bifurcation).

Evidence of a legitimate effort to design around the patent might help to rebut this de facto presumption. But at least one court has held that if an accused infringer refuses to waive privilege, it is not entitled to rely on evidence of its design-around efforts because it would be unfair for the patentee not to have the evidence with which to evaluate those efforts. Advanced Cardiovascular Sys. v. Medtronic, Inc., 265 F.3d 1294, 1309 10 (Fed. Cir. 2001). Under this approach, there will be little evidence indeed that a nonwaiving defendant can present to show that its conduct was not willful. 
subjective inquiry into willfulness with an objective one has some attractive features. It would do away with the requirement to obtain and disclose an opinion of counsel, since the accused infringer's state of mind would not matter. It would therefore prevent the distortions of legal advice we described above. The Federal Circuit's en banc order in Knorr-Bremse suggests that the court may be willing to consider treating willfulness as an objective standard; it asks the parties to brief the question whether proof of a substantial though ultimately unsuccessful defense to infringement should negate a finding of willfulness. ${ }^{92}$

Although an objective approach has substantial advantages over the current willfulness game, it is not really consistent with the concept of willfulness. Rather, such a standard would effectively punish accused infringers who raised unreasonable defenses, whether or not they knew those defenses were unreasonable. Further, as a practical matter it would require a jury to determine the relative quality of legal arguments without substantial experience in the range of such arguments. Patent law already has such a rule-it awards attorneys fees to prevailing patentees in exceptional cases. ${ }^{93}$ The point of willfulness is to focus on culpable conduct, which seems to require evidence of bad intent. The objective approach is not so much a bad idea as one that is orthogonal to the purposes of willfulness doctrine. It is really better thought of, therefore, as a variant of the proposal to abolish willfulness altogether, one that would enhance damages for some willful infringers and for some defendants who were not willful but whose arguments were weak.

\section{Redefining Willfulness}

A final solution to the willfulness game is to take a closer look at what constitutes willfulness. Patent law today defines willfulness on an ongoing basis. A company accused of infringement that adopts a product without knowledge of a patent may become a willful infringer once it learns of the patent, if it continues to sell the product. ${ }^{94}$ Indeed, even an accused infringer that has properly obtained and relied in good faith upon an opinion of counsel may be a willful infringer if it later discovers facts that undermine that reliance. The result is that even companies that adopt a technology in perfect good faith and exercise due care to avoid infringement when they later find out about a patent may ultimately be found to be willful infringers.

92. Knorr-Bremse, 344 F.3d at 1336.

93. 35 U.S.C. $\S 285$ (2000).

94. See supra note 18 and cases cited therein. 
Arguably this is a rather artificial definition of willfulness. It requires companies to make their product adoption decisions on a continuous basis, reevaluating whether to sell the product every time they learn new information. While in one sense this is an accurate portrayal of what companies do--business decisions are always subject to second-guessing as new information comes in-in a more important sense it is an unrealistic burden to impose. Deciding to produce a particular product involves making a series of investments in innovation, personnel, and in physical plant. ${ }^{95}$ This is particularly true if the company deciding to produce a product develops that product on its own. ${ }^{96}$ Once those investments have been made, the decision to continue producing is no longer made on a blank slate. A company that has invested $\$ 3$ billion in a new semiconductor fab ${ }^{97}$ or $\$ 800$ million in developing, testing, and marketing a new drug ${ }^{98}$ or even a few million dollars in a more mundane invention, can hardly be expected to throw those product-specific investments away every time the company is confronted with one of the more than two million patents currently in force in the United States. ${ }^{99}$ While those investments are sunk costs, once

95. See David J. Teece, Profiting from Technological Innovation: Implications for Integration, Collaboration, Licensing and Public Policy, 15 RES. POL'Y 285, 288-90 (1986) (discussing such "co-specific assets").

96. This is quite possible even if someone else has patented the invention, because patent law makes even independent development illegal. See, e.g., Fla. Prepaid Postsecondary Educ. Expense Bd. v. College Savings Bank, 527 U.S. 627, 645 (1999). For an argument that patent law should not do so, but rather should permit independent development to serve as a defense, as it does in trade secret and copyright cases, see Stephen M. Maurer \& Suzanne Scotchmer, The Independent Invention Defense in Intellectual Property, 69 ECONOMICA 535 (2002); see also Armond, supra note 83, at 117; John S. Liebovitz, Note, Inventing a Nonexclusive Patent System, 111 YALE L.J. 2251 (2002).

97. Mark LaPedus, Leading-Edge Fab Costs Soar to \$4 Billion, Silicon Strategies, at http://www.siliconstrategies.com/article/showArticle.jhtml?articleId=10801238 (Mar. 10, 2003); see also Steve Lohr, World-Class Chip, but a Fragile Business, N.Y. Times, Aug. 4, 2003, at $\mathrm{Cl}$ (noting that fabs cost two to three billion dollars each).

98. Estimates of the average cost of drug development and testing range from $\$ 150$ million to $\$ 500$ million; the latter is the industry's figure. Compare PHARM. RESEARCH AND MFrs. OF AM., Why Do Prescription Drugs Cost So MuCH ... AND OTHER QUESTIONS ABOUT YOUR MEDICINES (2000), available at http://www.phrma.org/ publications/publications/brochure/questions, with Public Citizen, Rebuttals to PhRMA Responses to the Public Citizen Report, "Rx R\&D Myths: The Case Against the Drug Industry's R\&D 'Scare Card",, at http:/www.citizen.org/congress/reform/drug industry/corporate/articles.cfm?ID $=6514$ (created Nov. 28, 2001). A recent estimate is even higher--over $\$ 800$ million per drug. See Gardiner Harris, Cost of Developing Drugs Found to Rise, WALl ST. J., Dec. 3, 2001, at B14.

99. The Information Products Division of the U.S. Patent and Trademark Office reports the number of utility patents issued each year, which has increased from 70,860 in 1986 to 166,039 in 2001 , with further increases in 2002 and likely in 2003 . Because the 
they have been made the cost of continuing to sell a product is far less than the cost of starting the development and investment process all over again for a new product. To make such a company liable for willful infringement merely because it came to believe at some point during litigation that the patent claim against them might have merit seems unfair. ${ }^{100}$ Imposing liability may also impose a substantial social cost in the form of wasted investment, since companies with significant potential financial exposure in a patent suit will be deterred from litigating close cases if their financial exposure will triple as a result. And it will likely discourage design-arounds by increasing the sanction for unsuccessful design-around efforts. This would result in a significant cost to society. Not only can design-arounds have collateral social benefits, but the law explicitly encourages efforts to design around a patented invention. ${ }^{101}$

The real goal of willfulness seems more modest. Willfulness law is designed to deter unscrupulous copyists from taking advantage of the patent disclosure in order to copy the patentee's invention and rush it to market. ${ }^{102} \mathrm{~A}$ much more circumscribed definition of willfulness, one that fo-

patent term ran for seventeen years from issue until the mid-1990s, all patents issued before this date in 1986 have yet to expire. Totaling these patents leads to roughly two million unexpired patents, depending on how many have issued in 2002 and 2003. U.S. PAT. \& TRADEMARK OfF., STATISTICAL RePORTS AVAILABLE FOR VIEWING, at http://www. uspto.gov/web/offices/ac/ido/oeip/taf/reports.htm\#PSR (last visited Oct. 28, 2003).

100. Indeed, the Federal Circuit has rejected in the strongest possible terms the idea that patentees should have to change their behavior merely because they are faced with a claim that they behaved inappropriately. In Kingsdown Medical Consultants, Ltd. v. Hollister, Inc., 863 F.2d 867 (Fed. Cir. 1988), the district court found inequitable conduct based in part on the patentee's continuation of the lawsuit after its error in prosecution was called to its attention. The federal circuit said:

[A] suggestion that patentees should abandon their suits, or disclaim or reissue, in response to every charge of inequitable conduct raised by an alleged infringer would be nothing short of ridiculous. The right of patentees to resist such charges must not be chilled to extinction by fear that a failure to disclaim or reissue will be used against them as evidence that their ... intent was deceitful.

Kingsdown Med., 863 F.2d at 875-76. The court to date has shown no similar solicitude for patent defendants who wish a chance to argue their case without being labeled willful as a result.

101. See Matthew J. Conigliaro et al., Foreseeability in Patent Law, 16 BerKELEY TECH. L.J. 1045 (2001) (discussing the law and policy arguments in favor of designarounds).

102. See, e.g., Seymour v. McCormick, 57 U.S. 480, 488-89 (1853) (describing the "wanton and malicious pirate" as the target of willfulness law). Indirect evidence of this can also be found in Federal Circuit decisions that find intentional copying to be a factor in aggravation of willful infringement. See, e.g., Electro Med. Sys. v. Cooper Life Scis., Inc., 34 F.3d 1048, 1058 (Fed. Cir. 1994) (denying enhanced damages, despite willful- 
cuses only on the accused infringer's state of mind at the time it initially adopts the product, can provide appropriate deterrence. An accused infringer that copies from the patent or the patented product should probably be liable for willful infringement, at least in the absence of evidence of a good faith belief that it was not infringing or that the patent was invalid. By contrast, an accused infringer who independently develops the invention, or even one who copies in good faith, doesn't seem particularly culpable merely because it later obtains a copy of the patent or discovers that the legal advice it obtained was faulty. Indeed, Matt Powers and Steven Carlson have reviewed the historic evidence in detail and concluded that, before the creation of the Federal Circuit, willful infringement meant deliberate copying, not continued use of an independently created invention. ${ }^{103}$

We suggest, therefore, that willfulness be redefined to focus only on the accused infringer's state of mind at the time she adopts the product in question. ${ }^{104}$ This narrower definition of willfulness would not only comport with the core purposes behind the willfulness requirement, but would solve a significant number of problems with the willfulness game. First, and most obviously, limiting the inquiry into state of mind to the time of the adoption decision would render all subsequent legal advice irrelevant. Courts would have no basis for compelling litigation counsel to waive the attorney-client or work product privileges. As a result, the problem of polluting litigation advice and settlement negotiations would be eliminated entirely. Second, because accused infringers would not have to disclose the later opinions of trial counsel, clients would be free to choose opinion counsel as trial counsel without fear of losing the attorney-client or work product privileges for litigation advice. ${ }^{105}$ Third, redefining willfulness in

ness, where the infringer did not engage in misconduct or copy the patented product); Amsted Indus. v. Buckeye Steel Castings Co., 24 F.3d 178 (Fed. Cir. 1994).

Doug Lichtman has argued to us that imposing extremely high damages remedies makes patent law more of a property rule and therefore encourages the negotiation of licenses. We are not persuaded. Patent law is already enforced by means of a property rule; injunctions are standard in virtually all cases once infringement is found. Trebling damages will raise the cost to an accused infringer of challenging a patent, and will therefore presumably deter some challenges to patents and increase patentee licensing revenue. But there is no reason to think that simply shifting the median damage award upwards will encourage more settlements, rather than just settlements at a higher price.

103. Powers \& Carlson, supra note 16, at 55-79.

104. Powers and Carlson make a similar suggestion among their several arguments for reform and we endorse their approach. See id. at 107-08.

105. It would probably still be unwise to choose the same lawyer or firm to write the opinion and litigate the case, because that lawyer would have to testify as to the opinion, 
this way would eliminate the costs associated with obtaining additional opinions of counsel as new facts come to light.

In addition, the refocused willfulness doctrine we propose would have one significant collateral benefit-it should reduce the utility of "submarine patents." Submarine patents are obtained after the product they are intended to cover has been put on the market by a competitor. They are based on a continuation application drafted specifically to cover the targeted product. ${ }^{106}$ Submarine patents have been much criticized, ${ }^{107}$ and they are particularly problematic precisely because of the current willfulness doctrine. Having been drafted to cover the particular device in question, they present an expensive challenge for even the most creative opinion counsel. Moreover, because the accused infringer necessarily has invested the costs to develop the product without being aware of the patent (because the patent did not exist during the product's development), the accused company will be faced with the particularly sharp dilemma of either risking a likely willfulness finding or walking away from its prior investment. Under our proposed reformulation, no submarine patent could ever support a willfulness claim against its intended target, which seems a substantial virtue.

This narrower definition of willfulness would not eliminate the need for written opinions of counsel altogether. A company that sought to make a new product would have to obtain such an opinion if it were aware of a patent that arguably read on that product. As a result, companies would still be faced with the problem of skewed pre-litigation advice and would still risk being trapped into a willfulness finding if they fail to obtain an opinion of counsel. Importantly, however, the number of circumstances in which an accused infringer would need to obtain such an opinion should decline sharply. Companies would only need an opinion of counsel if they were actually aware of a patent at the time they decided to adopt a product potentially covered by the claims of that patent. Companies that developed a product independently would, by definition, not be willful infringers, even if they later learned of the patent. Similarly, those that copied a product in the marketplace without knowledge that it was covered by a patent

and in doing so may tend to undermine his own case. But at least the risk of losing privilege would be gone.

106. For discussions of submarine patenting, see, for example, Stuart J.H. Graham, Hiding in the Patent's Shadow: Firms' Use of Secrecy to Capture Value from New Discoveries (Working Paper, 2002); Mark A. Lemley, An Empirical Study of the TwentyYear Patent Term, 22 AIPLA Q.J. 369 (1994); James W. Morando \& Christian H. Nadan, Silent Enemies, RECORDER, May 4, 1994, at 10.

107. See, e.g., Lemley \& Moore, supra note 81. 
would not be willful infringers, though the common practice of marking products with patent numbers would make this a smaller set of cases. ${ }^{108}$ Our anecdotal experience in litigation suggests that a significant number, perhaps even a majority, of all patent cases involve independent development. In none of these cases would the accused infringer have to obtain an opinion of counsel. Therefore none of these accused infringers would have to worry about skewed pre- or post-litigation advice, traps for the unwary, or limiting their choice of counsel.

This narrower definition of willfulness reduces but does not eliminate the incentive for clients to avoid reading patents. A company developing a new product would still have reason to avoid learning of patents that might cover that new product because running across such a patent would trigger their obligation to obtain a written opinion of counsel. A company's incentive to avoid reading patents would be somewhat lessened, however, because the consequences of doing so would be reduced. The company could be liable for willful infringement only for new products adopted with knowledge of the patent, not for existing products that it later happens to discover are infringing. Further, the costs of reading patents would be less than under the present system, since the scope of the privilege waiver would be substantially reduced. Nevertheless a significant number of companies would likely continue to be deterred from having their engineers read patents by the prospect of having to pay up to treble damages if found liable of willful infringement, coupled with the knowledge that in most cases the only viable way to fend off a finding of willful infringement is to obtain an opinion and then waive privilege.

That outcome not only frustrates the disclosure goal of patent law, but it also potentially reduces the total compensation paid to inventors. As noted above, there are many situations in which it is rational for a product maker to want to license an invention and for the inventor to grant a license. Such a mutually beneficial transaction is less likely to occur, however, if the would-be producer remains unaware of, and thus unable to request a license to, the invention because she is busily not reading patents. Accordingly, in the next part we return to the question whether, in addition to adjusting the temporal dimension of the willfulness inquiry, it is also necessary to adjust the financial dimension.

108. Marking or some other form of notice to the accused infringer is necessary to recover damages in the ordinary case. 35 U.S.C. $\$ 287$ (a) (2000). As a result, most patentees mark their products. 


\section{E. Adjusting the Willfulness Premium}

Current law permits enhancing damages upon finding willfulness but does not require it. ${ }^{109}$ Indeed, the Federal Circuit has held that district courts properly exercise their discretion by refusing to enhance damages for willfulness where the defendant's conduct does not look particularly culpable, even where the jury finds the conduct to be willful. ${ }^{10}$ Because the definition of willfulness sweeps so broadly, courts must determine whether even willful infringers have in fact behaved reprehensibly. Narrowing the definition of willfulness means that those who are found to be willful infringers would be truly culpable parties that have intentionally copied an invention without a good faith belief that they had a right to do so. Willfulness so defined ought to be deterred, and its victims ought to be made whole. Thus, were the courts to define willfulness to include copying with knowledge of a patent, we think it should compel a finding of enhanced damages. The question is: By how much should damages be enhanced? ${ }^{111}$

Our conceptual answer is: By the least amount possible needed to deter deliberate copyists and make the victims whole. We reach this answer because we believe first, that there are substantial negative consequences to over-deterrence and second, that there are significant deterrents to deliberate copying other than a willfulness penalty. As to the former, overdeterrence works against the disclosure goal of patent law by discouraging legitimate efforts to design around a patent at the margin. ${ }^{112}$ It also discourages engineers from reading patents, which not only reduces the spillover benefits of invention ${ }^{113}$ but tends to reduce the number of mutually-

109. See, e.g., Stryker Corp. v. Davol Inc., 234 F.3d 1252, 1259 (Fed. Cir. 2000); Cybor Corp. v. FAS Techs., 138 F.3d 1448, 1461 (Fed. Cir. 1998) (en banc).

110. See, e.g., Odetics, Inc. v. Storage Tech. Corp., 185 F.3d 1259, 1274 (Fed. Cir. 1999).

111. Under current law, courts consider deliberate copying, bad faith litigation conduct, size and financial condition, and the closeness of the legal issues as relevant factors in deciding how much damages should be enhanced. See Amsted Indus. v. Buckeye Steel Castings Co., 24 F.3d 178, 183-84 (Fed. Cir. 1994).

112. On the economic benefits of design-arounds, see, for example, Conigliaro et al., supra note 101 and cites therein.

113. On the economic benefits of spillovers from "leaky" intellectual property rights, see, for example, Dietmar Harhoff, R\&D Spillovers, Technological Proximity, and Productivity Growth-Evidence from German Panel Data, 52 SCHMALENBACH BuS. REV. 238 (2000). See also Ruslan LuKaCh \& Joseph Plasmans, MEasuring KNOWLedge SPILlovers Using PATENT CITATIONS: EVIDENCE fROM THE BELgIAN FIRM'S DATA (CESifo, Working Paper No. 754, 2002). Sector-specific productivity is directly and positively related to the level of spillover. Harhoff, supra, at 238. 
beneficial voluntary licensing transactions, thereby hurting patentees as well. As to the latter, deliberate copyists will, on the whole, fare worse on the merits of their liability cases, will have to pay their lawyers substantial fees in addition to any damages award, and will be subject to a permanent injunction that will deprive them of return on their investment in infringing physical plant. ${ }^{114}$

As noted, the principal basis for imposing a willfulness penalty in the first place is to make sure that intentional copyists wind up worse off than if they had not copied, and that the patentees whose work was copied wind up no worse off. Even if the willfulness penalty achieves these goals when imposed, intentional copyists will, as a systemic matter, have a slight incentive to copy, because the penalty will not always be imposed. Some copyists may escape detection by the patentee and the system will necessarily decide some cases incorrectly, thereby allowing a stray copyist here and there to escape. Accordingly, the willfulness penalty ("WP") should be set as follows: WP $=($ (gains from infringement $) \times(1 /$ probability of detection)) $+1 .^{115}$

We suggest that, for most cases, awarding successful willfulness plaintiffs their attorney fees will serve as an adequate willfulness penalty. ${ }^{16} \mathrm{An}$

114. Some infringers-even deliberate copyists-may be able to escape an injunction in rare cases if their infringing product serves some important social purposes. See Vitamin Technologists, Inc. v. Wis. Alumni Research Found., 146 F.2d 941, 944-47 (9th Cir. 1944) (refusing to grant injunction against cheap method of enhancing food with vitamin D); Milwaukee v. Activated Sludge, Inc., 69 F.2d 577, 593 (7th Cir. 1934) (refusing to grant injunction that would require closing the City of Milwaukee's sewage treatment plant). Those cases are the exception rather than the rule, however, and are most likely to be applied where the patentee does not itself manufacture the patented product. Foster v. Am. Mach. \& Foundry Co., 492 F.2d 1317, 1324 (2d Cir. 1974).

115. Thus, if the gains from infringement were $\$ 1,000,000$, and there was a 0.2 probability of detection, the willfulness penalty would be $\$ 5,000,001$; if the chance of detection rose to 0.9 , the willfulness penalty would be only $\$ 1,111,112$.

116. We say "most cases" because in cases in which detection is particularly unlikely, the penalty should be increased. Cases involving process patents or obvious efforts by the infringer to conceal its actions, such as by marking its infringing goods with the patentee's patent number and otherwise trying to pass off its goods as if they were the patentee's, would fall into this category.

It is possible that the trebling of current willfulness law corresponds, intentionally or otherwise, to the treble damages of the Clayton Act. The measure of damages in the Clayton Act was selected on the theory that, because antitrust conspiracies are hard to detect, the system needs to punish severely those that are detected. $C f$. United States v. Rabinowich, 238 U.S. 78, 88 (1915). The Supreme Court in Rabinowich stated:

For two or more to confederate and combine together to commit or cause to be committed a breach of the criminal laws is an offense of the gravest character, sometimes quite outweighing, in injury to the public, 
award of attorney fees will help reduce the likelihood that the patentee is undercompensated, and given that fees can be nontrivial, provide a modicum of monetary deterrence against copying. Of course, providing any willfulness penalty does not completely end the willfulness game, and therefore does not maximize the disclosure value of patents. Companies considering designing around a patent may still want to obtain and disclose an opinion of counsel in order to avoid paying attorney fees should they lose a subsequent patent suit. But simultaneously refocusing the willfulness inquiry on the time of adoption (thereby greatly limiting the scope of and costs imposed by the privilege waiver), and reducing the penalty itself would significantly increase the likelihood that companies will allow their engineers to read patents, and somewhat increase the likelihood that they forego the charade of opinion-getting altogether.

Patent law already provides for an award of attorneys fees in "exceptional cases." ${ }^{.17}$ It might seem odd as a matter of statutory interpretation to interpret two different statutory sections, one dealing with enhanced damages and the other with attorneys' fees, to provide the same remedy. But the oddity can be resolved by focusing on the purpose of the two different sections-to deter subjectively willful misconduct in the case of $\S 284$, and to increase remedies in cases that lacked an objectively reasonable defense in the case of $\S 285$. These cases might overlap-an infringer might both be improperly motivated and lack a substantial defense-but they are analytically distinct. ${ }^{18}$

\section{CONCLUSION}

In an effort to deter willful infringers, patent law has developed a bizarre complex of rules that has unintended consequences far outweighing the good of the rules themselves. Companies forced into the willfulness game must give up their legal rights and spend substantial amounts of money to defeat a charge of willful infringement. Imposing this burden distorts legal advice, impedes settlement, affects the choice of legal coun-

the mere commission of the contemplated crime. It involves deliberate plotting to subvert the laws, educating and preparing the conspirators for further and habitual criminal practices. And it is characterized by secrecy, rendering it difficult of detection, requiring more time for its discovery, and adding to the importance of punishing it when discovered.

$I d$. There is no similar problem in detecting most patent infringement, however.

117. 35 U.S.C. $\S 285(2000)$.

118. Alternatively, as we explained above, $\S 284$ could be interpreted to achieve a different purpose altogether-to correct for inadequate compensatory damages awards. 
sel, creates traps for the unsophisticated, and undermines the disclosure function of the patent system. Solving these problems requires the courts to end, if not the willfulness doctrine itself, at least the game-playing that surrounds it. Courts can begin by undoing the perverse rules that compel an accused infringer to obtain a written opinion of counsel and, having obtained that opinion, to disclose it. But eliminating these rules won't do away with the heart of the problem. That requires reconceptualizing willfulness based on the understanding that it is the copying of an invention, not merely competitive business conduct, that the law is designed to target. A narrower willfulness doctrine with a more limited financial penalty attached to it will more faithfully serve the purposes of patent law, and put an end to a longstanding and dangerous game. 
BERKELEY TECHNOLOGY LAW JOURNAL 